\title{
A new Andean treefrog (Amphibia: Hyloscirtus bogotensis group) from Ecuador: An example of community involvement for conservation
}

\author{
Mario H. Yánez-Muñoz ${ }^{\text {Corresp., } 1}{ }^{1}$, Juan Pablo Reyes-Puig ${ }^{1,2}$, Diego Batallas Revelo ${ }^{1,3}$, Callie Broaddus ${ }^{4}$, Miguel \\ Urgilés-Merchán $^{1}$, Diego F. Cisneros-Heredia ${ }^{1,5}$, Juan M. Guayasamin ${ }^{6,7}$ \\ 1 Unidad de Investigación, Instituto Nacional de Biodiversidad (INABIO), Quito, Pichincha, Ecuador \\ 2 Dirección de Reservas de Fundación Ecominga, Fundación Ecominga, Baños, Tungurahua, Ecuador \\ 3 Departamento de Biodiversidad Ecología y Evolución de la Facultad de Ciencias Biológicas, Universidad Complutense de Madrid, Madrid, Spain \\ 4 Reserva: The Youth Land Trust,, Washington, Washington, USA \\ 5 Museo de Zoología, Instituto iBIOTROP \& Instituto Biósfera, Colegio de Ciencias Biológicas y Ambientales,, Universidad San Francisco de Quito USFQ, \\ Quito, Pichincha, Ecuador \\ 6 Laboratorio de Biología Evolutiva, Instituto Biósfera-USFQ, Colegio de Ciencias Biológicas y Ambientales COCIBA, Universidad San Francisco de Quito, \\ Quito, Pichincha, Ecuador \\ 7 Department of Biology, University of North Carolina at Chapel Hill, Chapel Hill, North Carolina, United States \\ Corresponding Author: Mario H. Yánez-Muñoz \\ Email address: mario.yanez@biodiversidad.gob.ec
}

We provide several lines of evidence to delimit a new species of Hyloscirtus and define its phylogenetic position inside the Hyloscirtus bogotensis group. The new species is the sister taxon to Hyloscirtus mashpi and is related to a clade formed by $\mathrm{H}$. alytolylax and a putative new species from the province of El Oro in, southwestern Ecuador. Hyloscirtus conscientia sp. nov. is described from the montane forests of the Mira River basin in the extreme northwestern Ecuador. The new specie is characterized as follows tympanic annulus conspicuous, tip of snout in dorsal view subacuminate, middorsal stripe formed by melanophores larger and less dense, dorsal skin with individual iridophores forming dots, scarcely distributed across dorsum. Our study also highlights the importance of the Mira River Valley as a biogeographic barrier; suggesting research efforts north and south of the valley are likely to reveal additional endemic cryptic diversity. Finally, our partnership with Reserva: The Youth Land Trust, Rainforest Trust and EcoMinga Foundation has produced a novel and meaningful way to connect young people with biodiversity discovery and habitat conservation. 
1 A new Andean treefrog (Amphibia: Hyloscirtus

2 bogotensis group) from Ecuador: An example of

3 community involvement for conservation

4

5

6

7

8

Mario H. Yánez-Muñoz ${ }^{1 *}$, Juan P. Reyes-Puig, ${ }^{1,2}$, Diego Batallas ${ }^{1,3}$, Callie Broaddus ${ }^{4}$, Miguel A. Urgiles-Merchán ${ }^{1}$, Diego F. Cisneros-Heredia ${ }^{1,5}$ and Juan M. Guayasamin ${ }^{6,7}$

${ }^{1}$ Unidad de Investigación, Instituto Nacional de Biodiversidad (INABIO), Quito, Ecuador ${ }^{2}$ Fundación EcoMinga, Fundación Oscar Efren Reyes, Baños, Tungurahua, Ecuador

${ }^{3}$ Departamento de Biodiversidad Ecología y Evolución de la Facultad de Ciencias Biológicas, Universidad Complutense de Madrid, Madrid, España.

${ }^{4}$ Reserva: The Youth Land Trust, Washington, DC, USA ${ }^{5}$ Museo de Zoología, Instituto iBIOTROP \& Instituto Biósfera, Colegio de Ciencias Biológicas y Ambientales, Universidad San Francisco de Quito USFQ, Quito 170901, Ecuador.

${ }^{6}$ Laboratorio de Biología Evolutiva, Instituto Biósfera-USFQ, Colegio de Ciencias Biológicas y Ambientales COCIBA, Universidad San Francisco de Quito USFQ, Campus Cumbayá, Quito, Ecuador.

${ }^{7}$ Department of Biology, University of North Carolina at Chapel Hill, Chapel Hill, North Carolina, United States of America.

Corresponding Author:

Mario H. Yánez-Muñoz ${ }^{1}$

Pasaje Rumipamba 341 y Av. de Los Shyris, Quito-Ecuador.

Email address: mayamu@hotmail.com

\section{Abstract}

We provide several lines of evidence to delimit a new species of Hyloscirtus and define its phylogenetic position inside the Hyloscirtus bogotensis group. The new species is the sister taxon to Hyloscirtus mashpi and is related to a clade formed by H. alytolylax and a putative new species from the province of El Oro in, southwestern Ecuador. Hyloscirtus conscientia sp. nov. is described from the montane forests of the Mira River basin in the extreme northwestern Ecuador. The new specie is characterized as follows tympanic annulus conspicuous, tip of snout in dorsal view subacuminate, middorsal stripe formed by melanophores larger and less dense, dorsal skin with individual iridophores forming dots, scarcely distributed across dorsum. Our study also highlights the importance of the Mira River Valley as a biogeographic barrier; suggesting research efforts north and south of the valley are likely to reveal additional endemic cryptic diversity. Finally, our partnership with Reserva: The Youth Land Trust, Rainforest Trust and EcoMinga Foundation has produced a novel and meaningful way to connect young people with biodiversity discovery and habitat conservation. 
40

41

42

43

44

45

46

47

\section{Introduction}

Hyloscirtus Peters 1862 is a genus of stream-breeding treefrogs. Endemic to the Neotropics, it reaches its highest species richness in the northern Andes (Faivovich et al., 2005; Coloma et al., 2012; Frost 2021). With 37 formally described species, several studies have determined that Hyloscirtus contains four species groups: H. bogotensis group, $H$. armatus group, $H$. larinopygion group, and H. jahni group (Duellman, 1972, 1973; Faivovich et al. 2005; RojasRunjaic et al., 2018). The H. bogotensis group currently includes 17 species distributed across the Andes of Venezuela, Colombia, and Ecuador, and the lowlands of Costa Rica, Panama, Colombia, Ecuador, and Peru (Faivovich et al. 2005; Guayasamin et al. 2015, Rivera-Correa et al. 2016; Ron et al., 2018). Apparently, the only putative morphological synapomorphy of the bogotensis group is the presence of wide dermal fringes on fingers and toes (Faivovich et al. 2005); the presence of mental gland (Duellman, 1972) is considered a plesiomorphic character in Cophomantinae (Brunneti et al., 2015; Rivero-Correa et al. 2016; Faivovich et al. 2018). However, numerous studies support the monophyly of the group on the basis of molecular data (Faivovich et al., 2005; Coloma et al., 2012; Guayasamin et al., 2015; Rivero-Correa et al., 2016; Ron et al., 2018).

Species diversity within the H. bogotensis group is far from being fully understood. Guayasamin et al. (2015) revealed the existence of several cryptic lineages in the Hyloscirtus alytolylax species complex from the northwestern Andes of Ecuador. During the last five years, we have increased sampling efforts in northern Ecuador, particularly in the Mira River basin, near the border with Colombia. We have focused on this area because the Mira River has been identified as an important biogeographic barrier for small vertebrates and epiphytic plants (Croat, 2015; Baquero \& Zuchan, 2017; Yánez-Muñoz et al., 2018; Reyes-Puig et al., 2020; Brito et al., 2020).

In the course of this field work, we discovered a new cryptic species of Hyloscirtus, previously confused with $H$. alytolylax, that we describe below. We levereaged our taxonomic work to increase public awareness of the conservation issues surrounding this species and its habitat, and to test novel methods for engaging young people in scientific processes. 'Reserva: The Youth Land Trust' held a global contest to name this species which yielded hundreds of creative and thoughtful submissions, including the scientific and common names proposed for the new species described herein. This program exemplifies how engaging the public in scientific processes can be a powerful tool for raising awareness of biodiversity conservation.

\section{Materials and Methods}

Ethics statement. We conducted this study under research permits MAE-DNB-CM-2016-0045 and N ${ }^{\circ}$ MAE-DNB-CM-2019-0120, issued by the Ministerio del Ambiente del Ecuador. We followed the guidelines for use of live amphibians and reptiles in field research (Beaupre et al., 
2004), compiled by the American Society of Ichthyologists and Herpetologists, the Herpetologists' League and the Society for the Study of Amphibians and Reptiles.

Taxon sampling. We examined specimens deposited in the herpetological collections of the Instituto Nacional de Biodiversidad, Quito (DHMECN) and the University of Kansas, Lawrence (KU) (Appendix 1). All museum acronyms follow Sabaj (2016). Our taxonomic description employs several lines of evidence, including external morphological characters, linear morphometry variations, genetic divergence, monophyly, and geographic data. Similar approaches have been useful in recognizing and identifying closely related species of small vertebrates in the northern Andes (Yánez-Muñoz et al., 2018; Brito et al., 2020; Reyes-Puig et al., 2020).

The electronic version of this article in Portable Document Format (PDF) will represent a published work according to the International Commission on Zoological Nomenclature (ICZN), and hence the new names contained in the electronic version are effectively published under that Code from the electronic edition alone. This published work and the nomenclatural acts it contains have been registered in ZooBank, the online registration system for the ICZN. The ZooBank LSIDs (Life Science Identifiers) can be resolved, and the associated information viewed through any standard web browser by appending the LSID to the prefix http://zoobank.org/. The LSID for this publication is: LSID urna: 1sid: zoobank.org: pub: DCC900F2-B242-4357-9B85-D62C659EE135. LSIDurn:lsid:zoobank.org:act:38AD2D9656EF-4AE0-AD98-6E4057CCA0D7

Field work. Herpetological searches were conducted using visual encounter surveys, following methods proposed by Crump \& Scott (1994). Field work was conducted in the province of Carchi, Ecuador, during joint expeditions of the Instituto Nacional de Biodiversidad (INABIO) and Ecominga Foundation. We visited the following localities: (a) Río Pailón (0.983578397 N; 78.29651972 W; $1495 \mathrm{~m}$ ) on 06-11 November 2017, 19-25 August 2018, 15-20 September 2020, and 15-20 November 2020; (b) Río Baboso, Reserva Étnica Forestal Awa (0.923881 N, $78.432130 \mathrm{~W} ; 1117 \mathrm{~m}$ ), 16-22 July and 01-05 December 2019; (c) El Guapilal, Cerro Negro Reserva Dracula (0.891944 N, -78.20308 W, 1640-1750 m), 13-18 April 2020 and 22-27 September 2020. (d) Bosque Comunal la Esperanza (0.939753 N, -78.242000 W, 1699-1980 m), 22-31 March 2021.

Collected individuals were photographed alive and euthanized with benzocaine. A sample of muscle tissue was extracted and preserved in $95 \%$ ethanol. Specimens were fixed in $10 \%$ formalin and preserved in $75 \%$ ethanol.

Morphologic data and analysis. Species description follows the general format proposed by Duellman \& Hillis (1990) and Kizirian et al. (2003). Webbing formulae are described following Savage and Heyer (1980), with modifications by Myers and Duellman (1982). Sex and age were determined by identification of secondary sexual characteristics (nuptial pads and vocal slits in adult males) and direct gonad inspection through dorsolateral incisions. Morphometric 
120

121

122

123

124

125

126

127

128

129

130

131

132

133

134

135

136

137

138

139

140

141

142

143

144

145

146

147

148

149

150

151

152

153

154

155

156

157

158

measurements were taken with an electronic caliper (precision $\pm 0.01 \mathrm{~mm}$, rounded to $0.1 \mathrm{~mm}$ ), following descriptions and comments by Guayasamin et al. (2015). The following morphological measurements were taken in 50 males (Supplementary Material 1), corresponding to four species in the Hyloscirtus alytolylax species complex: snout-vent length (SVL), head length (HL), head width (HW), upper eyelid width (EW), interorbital distance (IOD), inter-nostril distance (IND), nostril eye distance (NED), eye diameter (ED), tympanum diameter (TD), hand length (HaL), tibia length (TL), and foot length (FL). We reduced the dimensionality of the morphometric data set, using a Principal Component Analysis (PCA), in order to determine the variability of a data set and ordered them by importance of their variables. Initially, data normality was determined using the Shapiro-Wilk test. As a second step, the influence of the SVL on the rest of the variables and its significance were determined, through a simple linear regression; for those variables where the SVL was significant (according to the analysis of covariance), the residuals of the linear regression were extracted, and the PCA was conducted with the residuals (Supplementary Material 1). The main components with eigenvalues greater than unity and that explain the highest percentage of the variation were used (Table1).

We also evaluated quantitative differences between Hyloscirtus mashpi Guayasamin et al., 2015 and the new species using univariate t-tests for independent samples for normal data, and Wilcoxon-Mann Whitney tests for differences in non-normal data. We tested data distribution with Shapiro-Wilk normality tests (Table 2).

Statistical analyses were conducted using the statistical package Past ${ }^{\circledR}$ (Hammer et al., 2001).

Call analysis. Recordings were obtained at Guapilal, Cerro Oscuro (Reserva Dracula) and El Baboso, province of Carchi, Ecuador, between 19:00-22:00 h in October and November 2019 by Mario H. Yánez-Muñoz and Juan P. Reyes-Puig. Calling individuals were recorded while perched on vegetation ca. $2 \mathrm{~m}$ above ground and close to streams. Vocalizations were obtained with an Olympus WS-802 digital recorder at a sampling frequency of $44.1 \mathrm{kHz}$ and 16 bits resolution. Calls were analyzed usingRaven ${ }^{\circledR} 1.5$ (Bioacoustics Research Program 2014), configured as a Hann-type window with $80 \%$ overlap and a size of 512 samples (11.6 ms). Figures of oscillograms and spectrograms were generated in R version 3.6.3 (R-DevelopmentCore-Team 2020), using packages tuneR (Ligges et al., 2018) and seewave (Sueur et al., 2008), with Hann window at $90 \%$ overlap with a size of 512 samples of the fast Fourier transform (FFT) and a spectral limit of $10 \mathrm{kHz}$. We used values of the analyzed parameters to calculate measures of central tendency (means), and dispersion (maximum, minimum, and standard deviation). Definitions, terms, and measurements follow, Köhler et al. (2017) and Sueur (2018). Calls of species of the Hyloscirtus bogotensis group were obtained from digital databases of Instituto Nacional de Biodiversidad, Quito (DHMECN) and the University of Kansas, Lawrence (KU), as well as acoustic information published by Guayasamin et al. (2015) (Table 3). Analog

Peer] reviewing PDF | (2021:03:59101:1:2:NEW 24 Jun 2021) 
159 files recorded in magnetic tape format were available and digitized following the procedures

160

161

162

163

164

165

166

167

168

169

170

171

172

173

174

175

176

177

178

179

180

181

182

183

184

185

186

187

188

189

190

191

192

193

194

195

196

197

198

proposed by Batallas \& Yánez-Muñoz (2020).

Genetic sampling. We generated eight new sequences for the mitochondrial 16S gene (see Fig. 1), following the primers and protocols described in Guayasamin et al. (2015). The new sequences were aligned with all those available for Hyloscirtus in GenBank (http://www.ncbi.nlm. nih.gov/genbank), originally published by Faivovich et al. (2005), CrawfordLips \& Bermingham, (2010), Coloma et al. (2012), Almendáriz et al. (2014), Guayasamin et al. (2015), and Ron et al. (2018).

Phylogenetic analysis. Sequences were aligned using MAFFT v. 7 (Katoh \& Standley, 2013) with the Q-INS-i strategy. Maximum likelihood (ML) trees were estimated using GARLI 2.01 (genetic algorithm for rapid likelihood inference; Zwickl, 2006). GARLI uses a genetic algorithm that finds the tree topology, branch lengths and model parameters that maximize $\operatorname{lnL}$ simultaneously (Zwickl, 2006). Individual solutions were selected after 10,000 generations with no significant improvement in likelihood, with the significant topological improvement level set at 0.01 . The final solution was selected when the total improvement in likelihood score was lower than 0.05 compared to the last solution obtained. Default values were used for other GARLI settings, as per recommendations of the developer (Zwickl, 2006). Bootstrap support was assessed via 1000 pseudoreplicates under the same settings used in tree search.

We note that our inferred phylogenetic tree is based on a single mitochondrial marker. Although it is well established that mitochondrial genes are informative when resolving recent evolutionary relationships (Avise \& Ayala, 2017), it is also true that sometimes gene trees do not agree with the true species tree (Degnan \& Rosenberg, 2009). Thus, our inferred tree should be seen as a hypothesis to be tested with additional gene markers.

\section{Results}

Phylogenetic relationships. The inferred topology (Fig. 1) agrees with Guayasamin et al. (2015), and differences are mostly explained by a more complete sampling in the Hyloscirtus alytolylax complex. The optimal phylogenetic tree recovered the new species as the sister taxon to $H$. mashpi and related to a clade formed by $H$. alytolylax and a putative new species from the southwestern Ecuador province of El Oro (Fig. 1). The uncorrected p genetic distance between the new species and its closest relatives are summarized in Table 4.

\section{Systematic accounts}

\section{Hyloscirtus conscientia sp. nov.}

LSID urna: 1sid: zoobank.org: pub: DCC900F2-B242-4357-9B85-D62C659EE135.

Peer] reviewing PDF | (2021:03:59101:1:2:NEW 24 Jun 2021) 
199

200

201

202

203

204

205

206

207

208

209

210

211

212

213

214

215

216

217

218

219

220

221

222

223

224

225

226

227

228

229

230

231

232

233

234

235

236

237

238

LSIDurn:Isid:zoobank.org:act:38AD2D96-56EF-4AE0-AD98-6E4057CCA0D7

Proposed standard Spanish name: Rana nubular torrenticola de Chical Proposed standard English name: Chical nubulous Stream-Frog

Holotype (Fig. 2, 3). DHMECN 13973, adult male collected at Reserva Dracula (0.983578397; 78.29651972 , 1495 m), Sector El Pailón Chico, province of Carchi, Republic of Ecuador, on 08 November 2017, by Mario H. Yanez-Muñoz, Juan P. Reyes-Puig and Fausto Recalde.

Paratypes (Fig. 4). DHMECN 13968-13972, DHMECN 13974-13977, same data as the holotype; DHMECN 15004, adult male, collected at Reserva Dracula (0.891944 N, -78.20308 W, $1750 \mathrm{~m}$ ), Sector El Guapilal, Cerro Negro, province of Carchi, Republic of Ecuador, on 23 September 2019, by Mario H. Yanez-Muñoz and Juan P. Reyes-Puig; DHMECN 15138-15140, DHMECN 15142, same data as DHMECN 15004, but collected on 13 April 2019, by Daniela Franco-Mena and Juan P. Reyes-Puig. DHMECN 16114-16114, females, Bosque de la Comuna La Esperanza, province of Carchi, Republic of Ecuador (0.939753 N, -78.242000 W, 1699m), on 24 March 2021, by Mario H. Yánez-Muñoz, Juan P. Reyes-Puig and Miguel Urgiles-Merchán.

Generic placement. We assign the new species to the genus Hyloscirtus Peters, 1882, as defined by Faivovich et al. (2008) and Rojas-Runjaic et al. (2015), and to the H. bogotensis species group (sensu Duellman 1972; Faivovich et al., 2005; Rojas-Runjaic et al., 2015) based on its phylogenetic position (Fig. 1) and morphology (i.e., wide dermal fringes on fingers and toes).

Diagnosis. Hyloscirtus conscientia sp nov. is characterized by the following combination of characters: (1) adult males small (SVL 29.6-33.3 mm, mean $=31.0 \pm 1.0, \mathrm{n}=14$ ), females (SVL $34.7-40 \mathrm{~mm}$, mean $=37.3 \pm 2.6 \mathrm{~mm}, \mathrm{n}=3$ ); (2) body relatively slender; (3) snout subacuminate in dorsal view and rounded in lateral view; (4) in life, dorsum usually pale yellowish-green, usually with a thin brown mid-dorsal stripe; (5) axillar and inguinal regions light yellowish-green; (6) mental gland present in males, pigmented in some individuals; (7) upper lip lacking white stripe; (8) parietal peritoneum white, visceral peritonea transparent; (9) iris grayish-brown to copper brown with thin black reticulation; (11) nuptial pad absent; (13) tympanic membrane pigmented as surrounding skin; tympanic annulus rounded and visible; (14) cream supraocular, supratympanic, and canthal stripes usually present; brown interorbital stripe usually present; (15) ulnar fold and tarsal stripe absent or inconspicuous; (16) calcar tubercle absent; (17) supracloacal fold low, with few iridophores; (18) low tubercles scattered around and below cloaca; (19) bones in life white; (20) elliptical prepollex not modified as a projecting spine; (21) dentigerous processes of vomers prominent, slightly curved, with a discernible gap and 10-14 teeth each; and (22) advertisement call with 5 or 6 notes, call duration $=470-632 \mathrm{~ms}$, and dominant frequency $=2.93-3.10 \mathrm{kHz}$. 
239

240

241

242

243

244

245

246

247

248

249

250

251

252

253

254

255

256

257

258

259

260

261

262

263

264

265

266

267

268

269

270

271

272

273

274

275

276

277

278

279

Comparison with similar species (Fig. 5, 6, 7, 8, 9, 10). Hyloscirtus conscientia sp. nov. is most similar to its sister species, H. mashpi Guayasamin et al., (2015), H. alytolytax (Duellman, 1972) and a new candidate species from southwestern Ecuador (Figs. 5, 6, 7). The variability in the morphological space (Fig. 8) was only explained in $39.89 \%$ by Principal Component 1 , the highest loads were the measurements of the hind limb (FL + TL) (Table 1). There is a considerable degree of overlap among four species included in the analysis. There are, however, some statistical differences; $H$. mashpi has a significantly larger eye diameter than $H$. conscientia sp. nov., as well as longer TL and HaL; and $H$. conscientia sp. nov. has significantly longer TD and NED than $H$. mashpi (Table 5, Fig. 9). Externally, Hyloscirtus mashpi differs from $H$. conscientia sp. nov. as follows (characters of $H$. conscientia sp. nov. in parentheses): ON/DIO ratio lower ( $80 \%$ in $H$. mashpi vs. $91 \%$ in $H$. conscientia sp. nov.), tympanic annulus inconspicuous (conspicuous), tip of snout in dorsal view truncate (rounded, Figs. 6B, 6C), middorsal stripe formed by melanophores smaller and more densely packed (mid-dorsal stripe formed by melanophores larger and less dense), dorsal skin with individual iridophores packed on top of melanophores but never forming dots (iridophores forming dots, scarcely distributed across dorsum; Figs.7B, 7C).

Hyloscirtus alytolylax differs from $H$. conscientia sp. nov. as follows (characters of $H$. conscientia sp. nov. in parenthesis): legs usually with thin white dorsal reticulum (absent; Fig. 10), ulnar and tarsal folds clearly present and covered by iridophores (absent or weak with faint white coloration), mid-dorsal stripe usually absent (thin mid-dorsal stripe usually present), iridophores forming abundant dots (iridophores forming scarcely distributed dots) (Fig. 7A, 7D). Two other species of the H. bogotensis group occur in the Pacific lowlands and western Andean slopes of Colombia and Ecuador: Hyloscirtus palmeri (Boulenger, 1908) and H. simmonsi (Duellman, 1989). Hyloscirtus palmeri clearly differs from $H$. conscientia sp. nov. by having calcars, while $H$. simmonsi differs by lacking cream supraocular, supratympanic, and canthal stripes (Fig. 6F). For a summary of traits that differentiate the new species from other closely related taxa, see Appendix 2.

Description of holotype (Figs. 2, 3). Adult male $31.7 \mathrm{~mm}$ SVL. Body relatively slender (Fig. 2). Head longer than wide (HL 33\% SVL; HW 33\% SVL). Snout subacuminate in dorsal view and rounded in lateral views; canthus rostralis distinct, slightly concave; loreal region slightly concave; lips rounded, not flared (Fig. 3). White canthal stripe present, incomplete (Fig. 3). Nostrils not protuberant, directed anterolaterally at level of anterior margin of lower jaw. Internarial region and top of head round. Interorbital distance longer than upper eyelid (IOD $129.63 \%$ EW). Eye prominent (ED 8\% SVL). Tympanic membrane visible, tympanic annulus evident, rounded, upper portion covered by supratympanic fold (TD 4\% SVL). Supratympanic fold starting at posterior end of upper eyelid and reaching posterior margin of insertion of arm (Fig. 2). Supratympanic stripe white. Mental gland present, diamond-shaped, partially covering the gular area and extending about half length of throat (Fig. 2). Dentigerous processes of vomers conspicuous, straight, narrowly separated from each other; each process bears 7 (right) and 8 (left) teeth. Choanae large, elliptical, not concealed by palatal shelf of maxillary arch. 
280 Tongue with a rounded outline, attached overall (narrowly free around lateral and posterior

281

282

283

284

285

286

287

288

289

290

291

292

293

294

295

296

297

298

299

300

301

302

303

304

305

306

307

308

309

310

311

312

313

314

315

316

317

318

319

320 margin); vocal slits present, longitudinal, originating on sides of tongue and extending to posterolateral corner of mouth. Vocal sac moderately distensible, evident externally, single, median and subgular. Forearm moderately robust; axillary membrane absent. Outer ulnar fold present. Fingers relatively short, thick, bearing small, ovoid discs; each disc only slightly expandable laterally, and with clearly defined circumferential groove; disc on finger III about the same width as TD. Relative length of fingers I $<$ II $<$ IV $<$ III. Fingers with fleshy dermal fringes; webbing present only between outer fingers; webbing formula II $2--3$ III $21 / 2-2-$ IV. Subarticular distal tubercle large and elliptical. Supernumerary tubercles present, fleshy and small. Palmar tubercle poorly differentiated. Inner metacarpal tubercle large, thick, elliptical. Broad elliptical prepollex, not modified as a spine. Nuptial excrescences absent. Hind limbs moderately robust; tibia length 49\% SVL; foot length 40\% SVL. Outer tarsal fold and calcar tubercle absent, with weak tarsal stripe; inner tarsal fold indistinct. Toes relatively short, with thin lateral fringes, bearing discs slightly smaller than those on fingers. Relative length of toes I $<$ II $<$ V $<$ III $<$ IV; extensive toe webbing, formula $\quad$ I 1-11/2 II 11/3-11/2 III 1+-12/3 IV 2$1 \mathrm{~V}$. Inner metatarsal tubercle elongate, elliptical, flat; subarticular tubercles small, round; outer metatarsal tubercle absent; supernumerary tubercles not distinctive. Cloacal opening directed posteroventrally at mid-level of thighs; supracloacal fold present, thick; conspicuous tubercles scattered around and below cloaca. Dorsal skin, gular and pectoral regions flanks smooth; venter aerolate. White parietal peritoneum present.

Coloration of holotype in preservative (Fig. 2). Dorsally yellowish-white, homogeneous. Melanophores scattered on eyelids and nasal region. White line on canthus, external border of upper eyelid and supratympanic fold. Outer edge of heel weakly pigmented white. Ventrally yellowish-white. Iris light brown with thin black reticulation.

Coloration of holotype in life (Figs. 10C). Dorsally homogeneously intense light green. Dorsum and dorsal surfaces of legs with small, well-defined white spots. Canthal surface finely dotted with melanophores. Creamy green canthal line (incomplete) and supratympanic fold. Venter white; throat, gular sac, and pectoral region transparent dark green; ventral surfaces of shanks pinkish green. Iris, creamy pinkish with fine dark brown spots around the pupil.

Measurements of the holotype (in mm). $\mathrm{SVL}=31.7 ; \mathrm{HW}=10.4 ; \mathrm{HL}=10.4 ; \mathrm{NED}=2.6$; IND= 2.7; $\mathrm{IOD}=3.5 ; \mathrm{EW}=2.7 ; \mathrm{TD}=1.3 ; \mathrm{ED}=3.5 ; \mathrm{TL}=15.7 ; \mathrm{HL}=9.6 ; \mathrm{FL}=12.8$.

Variation (Figs. 4, 11). Morphometric variation of the type series is presented in Table 6. In preservative (Fig. 4), the new species shows dorsal coloration varying from predominantly yellowish white with scattered little brown spots (DHMECN 15140) to a extremely pigmented dark brown pattern in a yellowish matrix (DHMECN 13969), passing through different combinations of dark brown with pale diffuse areas on limbs and flanks (DHMECN 15138) to partially pigmented with mid-dorsal and interorbital lines formed by brown melanophores 
321 (DHMECN 15004), either partially defined (DHMECN 13971) or dispersed in the head on a

322

323

324

325

326

327

328

329

330

331

332

333

334

335

336

337

338

339

340

341

342

343

344

345

346

347

348

349

350

351

352

353

354

355

356

357

358

359

white matrix (DHMECN 13974). Ventral coloration is immaculate white.

In life (Fig. 11), Hyloscirtus conscientia presents a wide range of dorsal color variation, with several patterns and intensity of brown pigmented melanophores in dorsal surfaces of the head and body, set in a yellowish green matrix, with a white or pale light green supratympanic fold. Some individuals also exhibit a mid-dorsal and interorbital lines composed of dense brown melanophores (Fig. 11). A light lemon-green morph has small brown points scattered on the dorsum, coloration becoming paler on flanks and limbs with scattered little brown spots, similar to other paler and darker intermediate morphs described above (Fig. 11). Iris coloration varies from silver to bronze, light brown, or whitish gray with black thin reticulations along the margin of the eye. Ventral coloration is predominantly white, males present a white to light green vocal sac, ventral surfaces of limbs are whitish-yellow. Field observations suggest that color can become darker or lighter as a form of chromatic crypsis used for camouflage.

Call description (Fig. 12, 13). The call of Hyloscirtus conscientia consists of a series of notes (5 or 6 notes per call). Call duration ranges from 470-655 ms. Note duration ranges from 16-35 $\mathrm{ms}$, with intervals between notes from 60-109 ms, emitted at a rate of 7.69-11.76 notes/second (Table 3). Each note has $2-4$ pulses. The dominant frequency ranges from $2.93-3.10 \mathrm{kHz}$. There are no visible harmonics.

Hyloscirtus conscientia sp. nov. presents a dominant frequency with values similar to other species belonging to the $H$. bogotensis group. However, the dominant frequency of $H$. conscientia sp. nov. is slightly higher than that reported for H. mashpi $(2.93-3.10 \mathrm{kHz}$ in the new species; 2.84-2.92 kHz in H. mashpi; Guayasamin et al., 2015; Table 3, Fig. 12). Other differences are the call duration (470-655 $\mathrm{ms}$ in $H$. conscientia sp. nov. and 331-380 $\mathrm{ms}$ in $H$. mashpi; Guayasamin et al., 2015) and the number of notes per call (5 or 6 in $\mathrm{H}$. conscientia sp. nov. 2 or 3 in H. mashpi; Guayasamin et al., 2015). The calls of Hyloscirtus conscientia sp. nov. and $H$. alytolylax sensu stricto are very similar (Table 3, Fig. 12) and the only non-overlapping trait is the time between notes $(60-109 \mathrm{~ms}$ in the new species; $35-60 \mathrm{~ms}$ in H. alotylylax; see Table 3).

The analyzed calls of the species in the Hyloscirtus bogotensis group exhibit two pattern types. Type 1, where emissions are short, but have multiple notes (explosive emissions) and a high emission rate (Table 6); this type of emission is present in the new species, $H$. alytolylax, $H$. mashpi and H. simmonsi (Fig. 12C, D, F). Type 2 emissions exhibit longer intervals between notes and a low emission rate (Table 6); this type of emission is characteristic of $H$. palmeri (Fig. $12 \mathrm{E})$.

PeerJ reviewing PDF | (2021:03:59101:1:2:NEW 24 Jun 2021) 
360

361

362

363

364

365

366

367

368

369

370

371

372

373

374

375

376

377

378

379

380

381

382

383

384

385

386

387

388

389

390

391

392

393

394

395

396

397

398

399

There is call variation within Hyloscirtus conscientia and nearby populations. For example, the call recorded at the San Juan River subbasin differs from the populations recorded in the Mira River subbasin (Fig. 12A, B). Through an analysis of its spectral and temporal parameters, we preliminarily suggest that this variation is an indicator that populations of San Juan River may be a candidate for a new species (Fig. 13; Table 6).

Distribution (Figs. 14). Hyloscirtus conscientia is known only from two nearby locality-pointsthe Dracula Reserve conservation area, managed by Ecominga Foundation, and Dracula Youth Reserve, managed by Reserva Youth Land Trust. Both reserves are located on the western slopes of the Andes, Carchi Province, northern Ecuador, at an altitude between 1495 to $1750 \mathrm{~m}$. The species is restricted to humid montane forest of the San Juan River drainage, in the Mira basin. Distribution points of Hyloscirtus conscientia are a few kilometers away from the EcuadorColombia border; thus, it is likely that $H$. conscientia is also present in Colombia.

Natural history. Hyloscirtus conscientia was found along clean-water streams with many waterfalls in montane foothill cloud forest. The riparian forest included trees reaching 20 meters high, covered by moss and epiphytes. Frogs were found at night, sitting on or under leaves and branches of Heliconiaceae, shrubs, trees, and ferns, at 30-350 cm above ground. Males were found calling while sitting under leaves in April, September and November. Hyloscirtus conscientia was found sympatric with Hyalinobatrachium sp. aff. valerioi, Espadarana prosoblepon, Rhaebo colomai, Atelopus coynei, and Pristimantis laticlavius.

Tadpoles, metamorphs, and juveniles were found in various months of the year (August, April, and November), suggesting several seasons of reproduction throughout the year. This may be a consequence of the constant high humidity and pluviosity of the Chocó bioregion.

Extinction risk. The new species distribution is limited to two localities in northwestern Ecuador, and both form part of the Dracula Reserve of Ecominga Foundation. The type localities are threatened by mining, cattle ranching, agriculture and deforestation. Field observations suggest that rivers and streams in the area are still free of invasive species, such as the rainbow trout, that have been shown to negatively impact frog communities (Martín-Torrijos et al. 2016; Krynak et al. 2020). Information on the species' biology, distribution, and ability to cope with threats, such as habitat fragmentation, emerging diseases, global change, and exotic species, is unknown. We suggest that Hyloscirtus conscientia be considered as Data Deficient, following the criteria by the IUCN, pending additional studies. However, if additional information confirm that the species is at risk, it may deserve to be classified under an extinction risk category in the near future.

Etymology. The specific epithet of the new species is a noun in apposition derived from the imperative Latin "consčentı̌a". This name was proposed by Carolina Bustillos, a 19 years old 
400 Ecuadorian that participated in a global, public contest to select the species name. When

401

402

403

404

405

406

407

408

409

410

411

412

413

414

415

416

417

418

419

420

421

422

423

424

425

426

427

428

429

430

431

432

433

434

435

436

437

438

439

explaining the species name, Carolina wrote: "We are at such a critical point in history, where the Earth and its species cannot continue to endure more exploitation and neglect by people. We are all part of this world and we must all have the consciousness to take care of it, to use less water, to use renewable energy sources, to consume less meat .... I think that this little frog should carry that message ... the message of being aware of how wonderful this land is, with all its flora and fauna, and of being aware that we should take care of it and be grateful to it."

The Spanish and English common names of $H$. conscientia refer to the habitat and location in which the species is found, in the cloud forests near the small town of El Chical, Ecuador. In the Spanish name, the word "Nubular" was explained by Domenique Benítez (14 years old, Ecuador) as a short, simple, and easy-to-memorize word of her own invention. She wrote, "although this word does not exist, it quickly describes the frog's habitat. I think the next generations should take into account that it is important to conserve species and name new ones in the future." The word "nubular" makes reference to the constant presence of clouds (Spanish: nubes) on these forests.

\section{Discussion}

Our results show another example of cryptic diversity in the Ecuadorian Andes. In recent years, thanks to the incorporation of molecular and acoustic data in taxonomic studies, has facilitated the discovery and description of hidden diversity (Hutter \& Guayasamin, 2015; Guayasamin et al., 2015; Brito, Batallas y Yánez-Muñoz 2017; Páez \& Ron, 2019; Ron et al., 2020; Guayasamin et al., 2020). These discoveries not only shed light onto the already dazzling diversity of the Andes, but also provide information regarding the importance of some biogeographic barriers that facilitate the isolation and diversification of lineages. One such barrier, supported in this study, is the Mira River Valley (Arteaga et al., 2016; Yánez Muñoz et al., 2018, 2020; Brito et al., 2020; Guayasamin et al, 2020; Reyes Puig et al., 2020;), which separates the new species from other closely related populations of the Hyloscirtus alytolylax complex.

At regional scale, biodiversity patterns northr of the Mira river show direct influence from mountain ridges on Cerro Golondrinas, an old geologic formation between the San Juan and Mira rivers, main tributaries of the drainage (Yánez Muñoz et al., 2020). This mountain barrier and the deep canyon formed by the Mira river promoted conditions for isolation and speciation, of species with low vagility in northwestern Ecuador, mainly in areas between the Mira and Esmeraldas rivers (Brito et al., 2020; Yánez Muñoz et al., 2019).

Our inferred phylogeny is congruent with other studies that support the monophyly of the Hyloscirtus bogotensis species group (Rojas-Runjaic et al. 2018, Guayasamin et al. 2015). This work shows high support for a clade formed by species of the Hyloscirtus alytolylax complex, including H. mashpi, H. conscientia, and a new candidate species from southwestern Ecuador.

Peer] reviewing PDF | (2021:03:59101:1:2:NEW 24 Jun 2021) 
440 Bioacoustic evidence showed differences between populations of Hyloscirtus located in different 441 tributary systems of the Mira basin (Mira and San Juan Rivers subbasins), leading us to refrain 442 from including this material as part of $H$. concientia. Further analyses are necessary to

443 understand the evolutionary relationships of the populations found at El Baboso, in the province 444 of Carchi province, and Alto Tambo in the province of Esmeraldas. Based on coloration pattern 445 analyses, populations from El Baboso (Mira River subbasin) are more similar to H. mashpi than 446 to $H$. conscientia, showing a distinctive mid-dorsal band composed by melanophores (usually 447 absent in $H$. conscientia). Females from the Alto Tambo populations, in the Santiago River basin 448 of Esmeraldas province, present a truncate snout tip and males have distinct calls (Fig. 6 and 13).

449

450

451

452

453

454

455

456

457

458

459

460

461

462

463

464

465

466

467

468

469

470

471

472

473

474

475

476

477

478

479 We consider this population as an unconfirmed candidate species.

\section{Community involvement and conservation}

Dracula Youth Reserve, one of the type localities of Hyloscirtus conscientia, is an ongoing project by Reserva: The Youth Land Trust to create an entirely youth-funded reserve, in partnership with Rainforest Trust and EcoMinga Foundation. Since September 2019, people aged 26 and younger have been contributing to the conservation of this species' habitat through individual donations, youth-led online fundraisers, and letters in support of conservation. In honor of these contributions, we invited youth to name this species through a free, online contest hosted on the Reserva: The Youth Land Trust website.

The contest was open to entrants aged 26 and younger throughout the month of September 2020. Participants were given a photo gallery and educational resources about the species and were allowed to submit a specific epithet, an English or Spanish name, and a justification for their choice in English or Spanish. We received 622 unique submissions from 36 countries, with an average participant age of 14.5. In the preliminary round of judging, each entry was read by four of 15 volunteer reviewers, and each entry that received at least two votes proceeded to the next round of judging. The final 54 entries were judged via video call by a panel of judges whose areas of expertise range from international conservation to space exploration: Ellen Stofan, Robert Ridgely, Georgie White, Luis E. Baquero, Grethel Aguilar, and Paula Kahumbu. Judges unanimously selected the winning specific epithet and assembled Spanish and English names from common themes found in 40 of the contest's entries.

The inclusion of a judging panel and expectation that entrants would review educational materials appears to have impacted the seriousness of responses, which were overwhelmingly positive, educated, and thoughtful attempts to offer a name for the species. The geographic range of participants (627 entries of 36 counties in South America, North America, Africa, and Europe) indicates that engaging the public in the naming of new species can be an effective method to educate those outside the scientific community, especially youth, on the importance of environmental issues and motivate communities both locally and globally to support conservation. 


\section{Conclusions}

482

483

We provide several lines of evidence to delimit a new species of Hyloscirtus and define its phylogenetic position inside the Hyloscirtus bogotensis group. Our study also highlights the importance of the Mira River Valley as a conspicuous biogeographic barrier; therefore, research efforts north and south of the valley are likely to reveal additional endemic cryptic diversity. Finally, our partnership with Reserva: The Youth Land Trust, Rainforest Trust and EcoMinga Foundation has produced a novel and meaningful way to connect young people with biodiversity discovery and habitat conservation.

490

491

492

493

494

\section{Acknowledgement}

We want to express our gratitude to Rainforest Trust and their "Species Legacy" program, to Orchid Conservation Alliance, and University of Basel for their support of EcoMinga

Foundation's efforts to protect the forest where the new species was discovered. Special thanks to Javier Robayo, Lou Jost and Heinz Schneider for their continuous support since the beginning of Dracula Reserve. We thank the many young people who submitted names - especially winners Carolina Bustillos and Domenique Benítez and those whose entries contributed to the final selection - and those who have provided financial support for the conservation of the habitat of the new species through Reserva: The Youth Land Trust. We greatly appreciate the participation of the following people as judges in the selection of the new name: Ellen Stofan, Robert Ridgely, Georgie White, Luis E. Baquero, Grethel Aguilar, and Paula Kahumbu. Tasman Rosenfeld provided numerous comments and suggestions to the manuscript. We appreciate the institutional support given by Francisco Prieto and Diego Inclan of INABIO. We thank the collaboration during field work by Jaqui Curay, Rocío Manovandas, Rubí García, Jorge Brito, Glenda Pozo, Jordi Salazar, Fausto Recalde, Mateo A. Vega-Yánez, Gabriela Puetate, Pearson Mc Govern, Natalia Espinoza, Daniel Valencia, Marco Montero, Andy Better, Julio Carrión, Mauricio Herrera-Madrid, Roberto Taicus and the "Dracula's Rangers" of Ecominga Foundation: Hector Yela, Milton Canticuz, Jeovany Guerra, Rolando Peña, Nilo Ortiz, David Yela. A special thanks to Roberto Taicus, president of the community of El Baboso for the facilities provided for exploration of Awa Forestal Reserve. Thanks to Mateo A. Vega-Yánez for his contribution in Map design. The work of MYM and JRP is part of the research program Diversidad de Pequeños Vertebrados de Ecuador, supported by INABIO through the project: "Conservación de la Biodiversidad en la Cuenca Binacional de los Ríos Mira-Mataje (MMRB): Construcción de Bases Biofísicas y Socio-ambientales para la Conservación y el Manejo Adaptativo de Servicios Ecosistémicos". Ministerio de Ambiente de Ecuador issued research permits and framework agreement for access to genetic resources. We thank the Inédita Program from the Ecuadorian

Science Agency SENESCYT (Respuestas a la Crisis de Biodiversidad: La Descripción de 518 Especies como Herramienta de Conservación; INEDITA PIC-20-INE-USFQ-001) that funded 519 the molecular component of this study. MYM dedicates this work to Patricia Bejarano, Alejandra patience during long absences. 
522

523

524

525

526

527

528

529

530

531

532

533

534

535

536

537

538

539

540

541

542

543

544

545

546

547

548

549

550

551

552

553

554

555

556

557

558

559

560

561

562

563

564

565

566

567

568

569

\section{References}

Almendáriz A, Brito J, Batallas D, Ron, SR. 2014. Una especie nueva de rana arbórea del género Hyloscirtus (Amphibia: Anura: Hylidae) de la Cordillera del Cóndor. Papéis Avulsos de Zoologia 54:33-49. 10.1590/0031-1049.2014.54.04.

Arteaga A, Pyron RA, Peñafiel N, Romero-Barreto P, Culebras J, Bustamante L, Yánez-Muñoz M, Guayasamin JM. 2016. Comparative phylogeography reveals cryptic diversity and repeated patterns of cladogenesis for amphibians and reptiles in Northwestern Ecuador. PloS one 11(4): e0151746. https://doi.org/10.1371/journal.pone.0151746

Avise, JC, Ayala, FJ. (Eds). 2017. In the Light of Evolution, Volume X: Comparative Phylogeography. Washington, DC: The National Academies Press.10.17226/23542.

Batallas D, Yánez-Muñoz MH. 2020. Descripción del canto de anuncio del sapo hojarasquero Rhaebo haematiticus (Cope, 1862) del suroccidente del ChocóBiogeográfico. Neotropical Biodiversity 6(1):1-6. 10.1080/23766808.2019.1706399

Baquero L, Zuchan K. 2017. Platystele pamelae (Orchidaceae: Pleurothallidinae), a new species from Ecuador. Lankesteriana 17(2): 245-250. 2017.10.15517/lank.v17i2.30112.

Beaupre SJ, Jacobson ER, Lillywhite HB, Zamudio K. 2004. Guidelines for use of live amphibians and reptiles in field and laboratory research. Lawrence: American Society of Ichthyologists and Herpetologists, 43.

Bioacoustics Research Program. 2014. Raven Pro: interactive sound analysis software (version 1.5). Ithaca (NY): The Cornell Lab of Ornithology. Available from: http:// www.birds.cornell.edu/raven.

Brito J, Batallas D, Yánez-Muñoz MH. 2017. Ranas terrestres Pristimantis (Anura: Craugastoridae) de los bosques montanos del río Upano, Ecuador: Lista anotada, patrones de diversidad y descripción de cuatro especies nuevas. Neotropical Biodiversity 3(1): 125-156. 10.1080/23766808.2017.1299529

Brito J, Koch C, Percequillo AR, Tinoco N, Weksler M, Pinto CM, Pardiñas UFJ. 2020. A new genus of oryzomyine rodents (Cricetidae, Sigmodontinae) with three new species from montane cloud forests, western Andean cordillera of Colombia and Ecuador. PeerJ 8:e10247. 10.7717/peerj.10247

Brunetti AE, Hermida GH, Luna MC, Barsotti AMG, Jared C, Antoniazzi MM, Rivera-Correa MR, Berneck BVM, Faivovich J. 2015. Diversity and evolution of sexually dimorphic mental and lateral glands in Cophomantini treefrogs (Anura: Hylidae: Hylinae), Biological Journal of the Linnean Society, 114 (1) 12-34.https://doi.org/10.1111/bij.12406

Crawford AJ, Lips KR, Bermingham E. 2010. Epidemic diseasedecimates amphibian abundance, species diversity, andevolutionary history in the highlands of central Panama. Proceedings of the National Academy of Sciences 107:13777-13782. 10.1073/pnas.0914115107

Crump ML, SCOTT NJ. 1994. Visual Encounter Surveys. Pp. 84-92. In: Heyer WR, Donnelly MA, Mcdiarmid RW, Hayek LC, Foster MS. (Eds). Measuring and Monitoring Biological Diversity: standard methods for amphibians. Smithsonian Institution Press, Washington D.C.

Coloma LA, Carvajal-Endara S, Dueñas JF, Paredes-Recalde A, Morales-Mite M, AlmeidaReinoso D, Tapia, EE, Hutter CR, Toral E. and Guayasamin JM. 2012. Molecular Phylogenetics of stream treefrogs of the Hyloscirtus larinopygion group (Anura: Hylidae), and description of two new species from Ecuador. Zootaxa, 3364, 1-78. 10.11646/zootaxa.3364.1.1

Croat T. 2015. A Review of Studies of Neotropical Araceae. Aroideana 38 (1):44-54. 
570

571

572

573

574

575

576

577

578

579

580

581

582

583

584

585

586

587

588

589

590

591

592

593

594

595

596

597

598

599

600

601

602

603

604

605

606

607

608

609

610

611

612

613

614

615

616

617

618

619

620

Degnan, J.H., Rosenberg, N.A. 2009. Gene tree discordance, phylogenetic inference and the multispecies coalescent. Trends in Ecology \& Evolution 26 (6), 332-340.

10.1016/j.tree.2009.01.009

Duellman WE. 1972. A review of the neotropical frogs of the Hyla bogotensis group. Occasional Papers of the Museum of Natural History University of Kansas 11:1-31.

Duellman WE. 1973. Descriptions of new hylid frogs from Colombia and Ecuador. Herpetologica 29 (3): 219-227.

Duellman WE, Hillis DM. 1990. Systematics of frogs of the Hyla larinopygion group. Occasional Papers of the Museum of Natural History, The University of Kansas 134: 1-23.

Faivovich J, Haddad CFB, Garcia de A, Frost DR, Campbell JA, Wheeler WC. 2005. Systematic review of the frog family Hylidae, with special reference to Hylinae: a phylogenetic analysis and taxonomic revision. Bulletin of the American Museum of Natural History 294: 1-240. 10.5531/sd.sp.12

Faivovich J, Pereyra M, Luna MC, Hertz A, Blotto BL, Vásquez-Almazán CR, McCranie JM, Sánchez DA. 2018. Monophyly and Relationships of Several Genera of Hylini (Anura: Hylidae: Hylinae), with Comments on Recent Taxonomic Changes in Hylids. South American Journal of Herpetology 13(1):1-32. DOI: 10.2994/SAJH-D-17-00115.1

Guayasamin JM, Rivera-Correa M, Arteaga A, Culebras J, Bustamante L, Pyron RA, Peñafiel N, Morochze C, Hutter CR. 2015. Molecular phylogeny of stream treefrogs (Hylidae: Hyloscirtus bogotensis Group), with a new species from the Andes of Ecuador. Neotropical Biodiversity 1: 2-21. 10.1080/23766808.2015.1074407

Guayasamin JM, DF Cisneros-Heredia, RW McDiarmid, P Peña, CR Hutter 2020. Glassfrog of Ecuador: diversity, evolution and conservation. Diversity 12 (222): 1-285. 10.3390/d12060222

Gelman A, Rubin DB. 1992. Inference from iterative simulation using multiple sequences. Statistical science 7(4):457-472.

Gómez N, Gallego B, and Naranjo LG. (Eds.). 2017. Atlas socioambiental de las cuencas transfronterizas Mira y Mataje: aportes para su ordenamiento y gestión integral Colombia - Ecuador. (pp. 110 - 111). Santiago de Cali, Colombia: WWF-Colombia, Editorial El Bando Creativo.

Hammer Ø., Harper, D.; Ryan, P.D. 2001. Past: Paleontological Statistics Software package for education and data analysis. Paleontologia Electron. 4(1): 9 pp. Available from. http//paleo-electronica.org/2001_1/past/issue1_01.htm

Hutter, C., J. M. Guayasamin. 2015. Cryptic diversity concealed in the Andean cloud forests: two new species of rainfrogs (Pristimantis) uncovered by molecular and bioacoustic data. Neotropical Biodiversity 1: 36-59. 10.1080/23766808.2015.1100376

Katoh K, Standley DM. 2013. MAFFT multiple sequence alignment software version 7: improvements in performance and usability. Molecular Biology and Evolution. 30 (4):772-780. 10.1093/molbev/mst010

Kizirian D, Coloma LA, Paredes-Recalde A. 2003. A new tree-frog (Hylidae: Hyla) from southern Ecuador and a descrip-tion of its antipredator behavior. Herpetologica 59:339349. 10.1655/02-41

Köhler J, Jansen M, Rodríguez A, Kok PJR, Toledo LF, Emmrich M, Glaw F, Haddad CFB, Rödel M. \& Vences, M. 2017. The use of bioacoustics in anuran taxonomy: theory, terminology, methods and recommendations for best practice. Zootaxa 4251(1): 1-124. 10.11646/zootaxa.4251.1.1

Krynak KL, Wessels DG, Imba SM, Krynak TJ, Snyder EB, Lyons JA, Guayasamin JM. 2020. Call survey indicates rainbow trout farming alters glassfrog community composition in the Andes of Ecuador. Amphibian \& Reptile Conservation 14(2):1-11.

Ligges U, Krey S, Mersmann O, and Schnackenberg S. 2018. tuneR: Analysis of music. R package versión 1.3.3. Available from: https://CRAN.R project.org/package=tuneR

Peer) reviewing PDF | (2021:03:59101:1:2:NEW 24 Jun 2021) 
621

622

623

624

625

626

627

628

629

630

631

632

633

634

635

636

637

638

639

640

641

642

643

644

645

646

647

648

649

650

651

652

653

654

655

656

657

658

659

660

661

662

663

664

665

666

667

668

669

Martín-Torrijos LM, Sandoval-Sierra JV, Muñoz J, Diéguez-Uribeondo J, Bosch J, Guayasamin J. M.. 2016. Rainbow trout (Onchorhynchus mykiss) threaten Andean amphibians. Neotropical Biodiversity 2: 26-36. https://doi.org/10.1080/23766808.2016.1151133

Myers CW, Duellman WE. 1982. A new species ofHylafromCerro Colorado, and other tree frog records and geo-graphical notes from western Panama. American Museum Novittates 2752:1-32.

Páez NB, Ron SR. 2019. Systematics of Huicundomantis, a new subgenus of Pristimantis (Anura, Strabomantidae) with extraordinary cryptic diversity and eleven new species. ZooKeys 868: 1-112. 10.3897/zookeys.868.26766

R Development Core Team. 2019. R: A language and environment for statistical computing (version 3.5.3). Vienna, Austria: R Foundation for Statistical Computing. Available from: http://www.R-project.org

Reyes-Puig C, Bittencourt-Silva G, Torres-Sánchez M, Wilkinson M, Streicher J, Maddock S, Kotharambath R, Müller H, Angiolani Larrea F, Almeida-Reinoso D, Ron S, CisnerosHeredia D. 2019. Rediscovery of the Endangered Carchi Andean Toad, Rhaebo colomai (Hoogmoed, 1985), in Ecuador, with comments on its conservation status and extinction risk. Check List 15 (3): 415-419. 10.15560/15.3.415

Reyes-Puig C, Wake DB, Kotharambath R, Streicher JW, Koch C, Cisneros-Heredia DF, Yánez-Muñoz MH, Ron S. 2020. Two extremely rare new species of fossorial salamanders of the genus Oedipina (Plethodontidae) from northwestern Ecuador. PeerJ 8:e9934. 10.7717/peerj.9934

Rivera-Correa M, García-Burneo K, Grant T (2016) A new red-eyed of stream frog of Hyloscirtus (Anura: Hylidae) from Peru, with comments on the taxonomy of the genus. Zootaxa 4061: 29-40. 10.11646/zootaxa.4061.1.3

Rojas-Runjaic JM, Infante-Rivero EE, Salerno PE, Meza-Joya FL (2018) A new species of Hyloscirtus (Anura, Hylidae) from the Colombian and Venezuelan slopes of Sierra de Perijá, and the phylogenetic position of Hyloscirtus jahni (Rivero, 1961). Zootaxa 4382: 121-146. 10.11646/zootaxa.4382.1.4

Ron SR., Caminer M., Varela-Jaramillo A., Almeida-Reinoso D. 2018. A new treefrog from Cordillera del Cóndor with comments on the biogeographic affinity between Cordillera del Cóndor and the Guianan Tepuis (Anura, Hylidae, Hyloscirtus). ZooKeys 809: 97124.group. ZooKeys 993: 121-155. 10.3897/zookeys.993.53559

Ronquist F, Huelsenbeck J. 2003. MrBayes 3: Bayesian phylogenetic inference under mixed models. Bioinformatics 19:1572-1574. 10.1093/bioinformatics/btg180

Sabaj MH. 2016. Standard Symbolic Codes for Institutional Resource Collections in Herpetology and Ichthyology: an Online Reference. Available at http://www.asih.org/, American Society of Ichthyologists and Herpetologist.

Sueur J. 2018. Sound Analysis and Synthesis with R. Cham, Switzerland: Springer.

Sueur J, Aubin T, and Simonis C. 2008. Seewave: a free modular tool for sound analysis and synthesis. Bioacoustics 18:213-226.

Swofford DL. 2012. PAUP: Phylogenetic Analysis Using Parsimony ( ${ }^{*}$ and Other Methods). Version 4. Sinauer Associates, Sunderland, Massachusetts.

Yánez-Muñoz MH, Reyes-Puig C, Reyes-Puig JP, Velasco JA, Ayala-Varela F, and TorresCarvajal O. 2018. A new cryptic species of Anolis lizard from northwestern South America (Iguanidae, Dactyloinae). Zookeys 794:135-163. 10.3897/zookeys.794.26936

Yánez-Muñoz MH, Batallas D, Franco-Mena D, Meza-Ramos PA, Oyagata LA, PadillaD, Paucar C, Reyes-Puig JP, Rodríguez A, Urgilés-Merchán MA, Vega-Yánez M. 2020.Anfibios en los Ecosistemas Andino-Tropicales de la provincia del Carchi. INABIO - GADPC.

Peer] reviewing PDF | (2021:03:59101:1:2:NEW 24 Jun 2021) 
670 Zwickl DJ. 2006. Genetic algorithm approaches for the phy- logenetic analyses of large biological sequence data- sets under the maximum likelihood criterion [dissertation]. Austin: The University of Texas at Austin. 


\section{Figure 1}

Figure 1. Evolutionary relationships of species in the genus Hyloscirtus inferred using Maximum likelihood, based on the mitochondrial gene $16 \mathrm{~S}$.

Each terminal is followed by its corresponding museum number, Genbank accession code, and locality. Sequences generated in this study are in blue (added upon acceptance of the manuscript). 
Outgroup: Species in the Hyloscirtus larinopygion Group

H. colymba (AY843620, Panama: Parque Nacional El Cope) H. alytolylax (CJ-5212, MW692908, Ecuador: Intag/Junin) H. alytolylax (CJ.5225, MW692909, Ecuador: Intag/Junip) - H. alytolylax (MZUTI-1707, KT 279536, Ecuador: Reserva Los Cedros) H. alytolylax (MZUT1-1705, KT279537, Ecuador: Reserva Los Cedros) H. alytolylax (MZUTI-1706, KT279538, Ecuador: Reserva Los Cedros)

- H. alytolylax (DHMECN-5876, MW692913, Ecuador: Mindo-San Carlos) H. alytolylax (DHMECN-5877, MW692914, Ecuador: Mindo-San Carlos) H. alytolylax (MZUTI-1921, KT279534, Ecuador: San Francisco de las Pampas) H. alytolylax (MZUTI-1917, KT 279535, Ecuador: Tandapl) H. alytolylax (MZUTI-1919,KT279539, Ecuador: Tandapi) H. alytolylax (MZUT1-464, KI 279541, Ecuador: Reserva Las Gralarias) H. alytolylax (MZUT1-46, KT279542, Ecuador: Reserva Las Gralarias) H. alytolylax (MZUT1-409, KT279543, Ecuador: Las Gralarlas) H. alytolylax (MZUT1-346, KT279540, Ecuador: Mindo) H. alytolylax (QCAZ-24377, JX155825, Ecuador: San Francisco de las Pampas) H. alytolylax (QCAZ-24376, JX155826, Ecuador: San Francisco de las Pampas) Hyloscirtus sp (DHMECN-13795, MW692912, Ecuador: Ayampa)

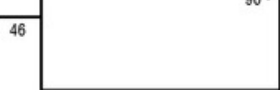

100

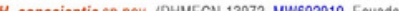
100 H. conscientia sp nov (DHMECN-13973, MW6992911, Ecuador: El Pallon)
H. masphi (MZUTI-613, KT279523, Ecuador: Reserva Mashpi) H. masphi (MZUT1-3097, KT 279524, Ecuador: MIlpe)

H. masphi (MZUT1-3518.KT279525, Ecuador: Reserva Mashipi) H. masphi (MZUTI-614,KT279526, Ecuador: ReservaMashpi) H. masphi (MZUT1-609,KT279527, Ecuador: Reserva Mashipl) H.masphi (MZUTI-3096,KT 279528, Ecuador: Milpe)

100 H. masphi ( MZUTI-612, KT 279529, Ecuador: Reserva Mashpi) H. masphi ( MZUT1-610,KT279530, Ecuador: Reserva Mashpi) H. masphi (MZUT1-3098,KT279531, Ecuador: Milpe) H.masphi (MZUTI-3747,KT279532, Ecuador: Milpe)

H. masphi (M7UTI 606. KT 27953, Ecuador: Reserva Mashpil)

H.lascinius (MHN.S-19163, MG596762, Venezuela: Slerra de Perrja) 100 H. lascinius (MHinLS-19164,MC596763, Venezuela:Sierra de Perriaj)

97 H. palmeri (AY843650, Panamá: Parque Nacional Omar Torrijios) H. palmeri (KRL 1038, FJ784457, Panama: Parque Nacional Omar Torrijos H. palmeri (KRLL216, FJ784493, Panama: Parque Nacional Omar Torrijos) H. palmeri (KRL. 1592, FJ784568, Panama: Parque Nacional Omar Torrijos) H. palmeri (KRLL1626, FJ784573, Panamá: Parque Nacional Omar Torrilos) H.palmeri (KRLL1636, FJ784577, Panama: Parque Nacional Omar Torrtjos) H.palmeri (TOE_141, FJ784596, Panama: Parque Nacional Omar Torrijos H. palmeri (MZUT1-608, KT 279549, Ecuador: Reserva Mashpi) H. palmeri (MZUT1-3083,KT279551, Ecuador: Milpe) H. palmeri (MZUT1-607,KT279550, Ecuador: Reserva Mashpi)

phyllognathus (QCAZ-23938,JX155827, Ecuador: Miazi Alto) H. phyllognathus (OCAZ-41032,JX155828,Ecuador: Miazi Alto)

- H. phyllognathus (OCAZ-32271, JX155829, Ecuador: Nueve de Octubre)

$100[$ H. phyllognathus (MZUTI-2383, KT 279545, Ecuador: Lago Agrio)

H. phyllognathus (MZUT1-2384,KT279546, Ecuador: Lago Agrio 96 H. phyllognathus (MZUTI-2385,KT27954, Ecuador: Lago Agrio)

28 H. phyllognathus (MZUT1- 2386, KT279548, Ecuador: Lago Agrio) H. japreira (MHNLS-18888, MG596766, Venezuela: Slerra de Perliá)
H. japreira (MHNLS-18988, MG596767, Venezuela: Slerra de Perliá)

H. japreira (MHNLLS-19235, MG596769, Venezuela: Sierra de Perijâ..)

H. japreira (UIS-A.5496, MC596770, Venezuels: Sierra fe Pert'a)

H. japreira (UIS-A. 5497,MG596771,Venezuela: Slerra de Perija)

100 H. platydactylus ( MHNLS-20321,MG596772, Venezuela: Merilda, Quebrada la Sucia) H. platydactyius (MHNL.S.20322, MG596773, Venezuela: Merida, Quebrada la Sucla) H. platydactyius (MHNLLS-20325,MG596774,Venezuela: Merida, Quebrada la Sucia) H. platydactyius (MHNLLS. 20326, MG596775, Venezuela: Merida, Quebrada la Sucla) H. callipeza (UIS-A-5947,MC596780, Colombla: Reserva Nucleo Arnania H. tapichalaca (QCAZ-15083, JX155830, Ecuador: Reserva Tapichalaca)

H. condor (MEPN14758, KF 756938, Ecuador: Coordllera del Condor, Reserva Cerro Plateado) 98 H. condor (MEPN14754,KF756939Ecuador: Coordillera del Condor, Reserva Cerro Plateado) Hyloscirtus armatus (AMNH-A-1651632, Y549321, Bolivia: Parque Nacional Amboro)

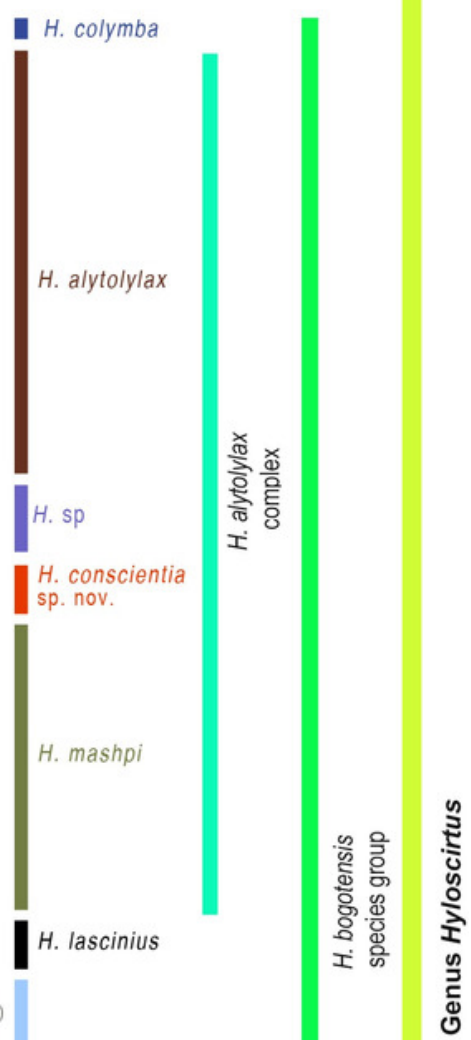

H. palmeri

H. phyllognathus

H. japreira

H. platydactylus

H. callipeza

H. tapichalaca

H. condor

H. armatus 


\section{Figure 2}

Figure 2. Dorsal, ventral and profile views of Hyloscirtus conscientia sp. nov., male adult (DHMECN 13973).

Photographs MYM.

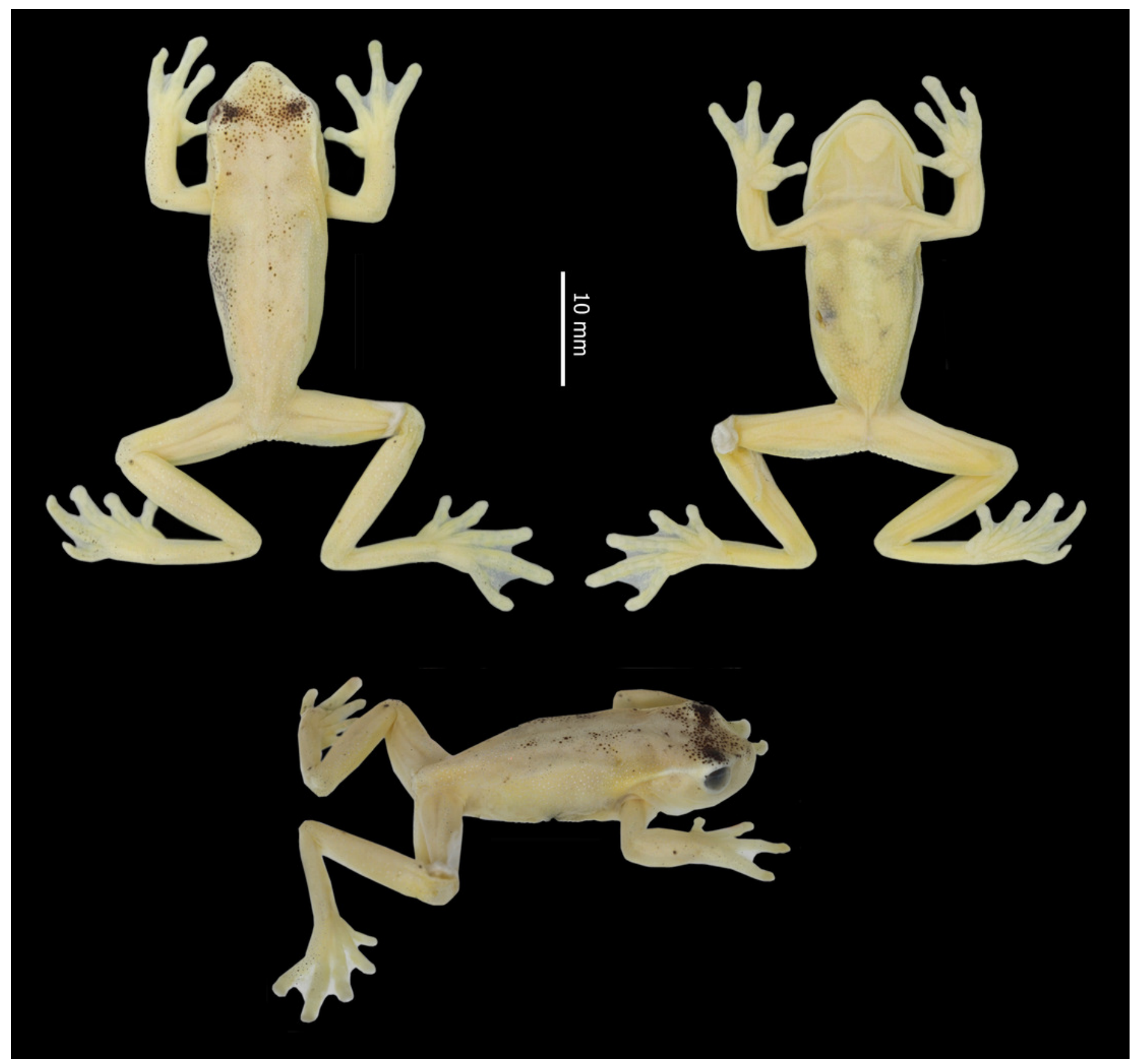


Figure 3

Figure 3. Detail of head in dorsal and profile view, and hands and feet of Holotype of Hyloscirtus conscientia sp. nov., male adult (DHMECN 13973).

Photographs MYM. 


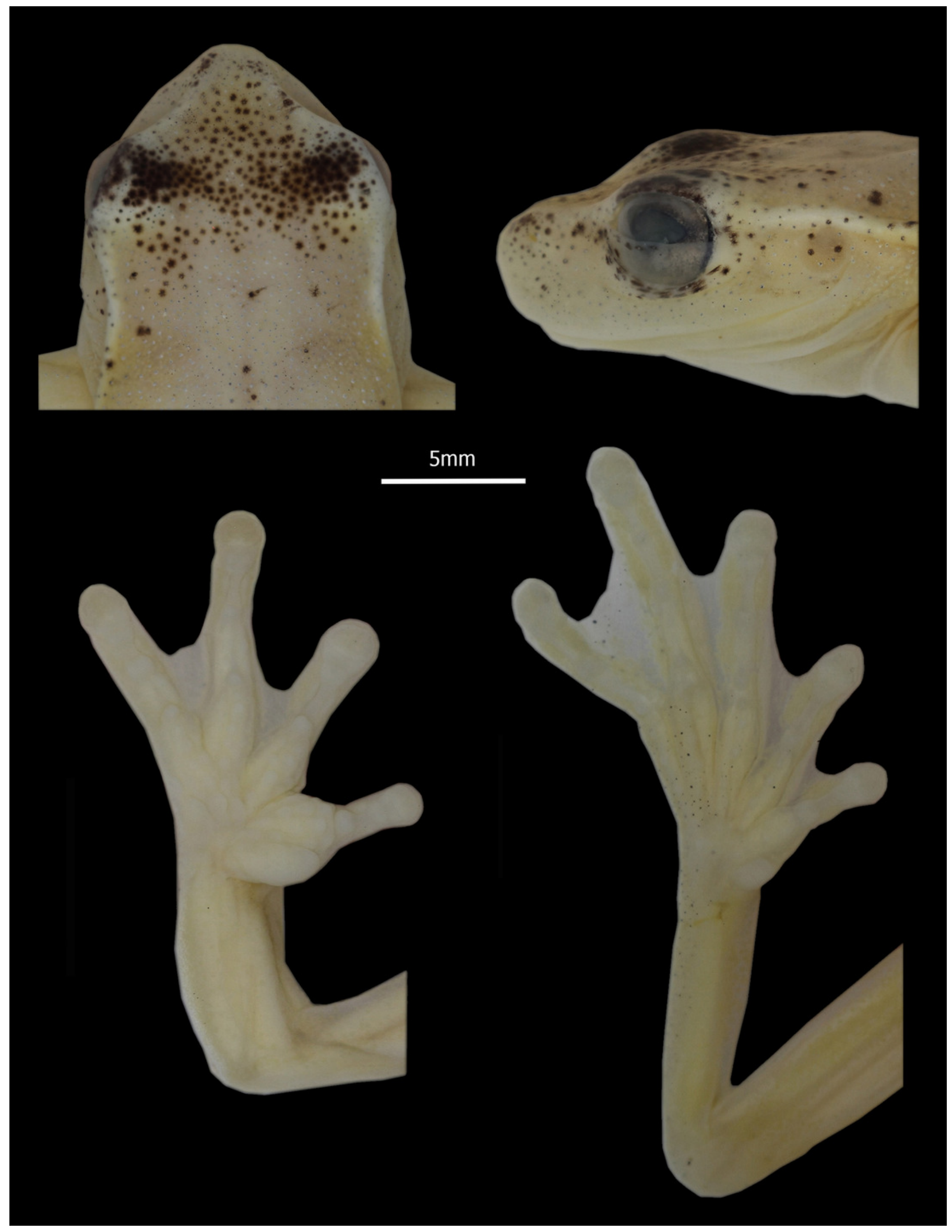




\section{Figure 4}

Figure 4. Variation of type series of Hyloscirtus conscientia sp. nov. in preservative.

First row, from left to right: DHMECN 15140, DHMECN 15139, DHMECN 13973, Holotype, DHMECN 13974. Second row, from left to right: DHMECN 13971, DHMECN 15004, DHMECN 15138, DHMECN 13969. Photographs by MYM.

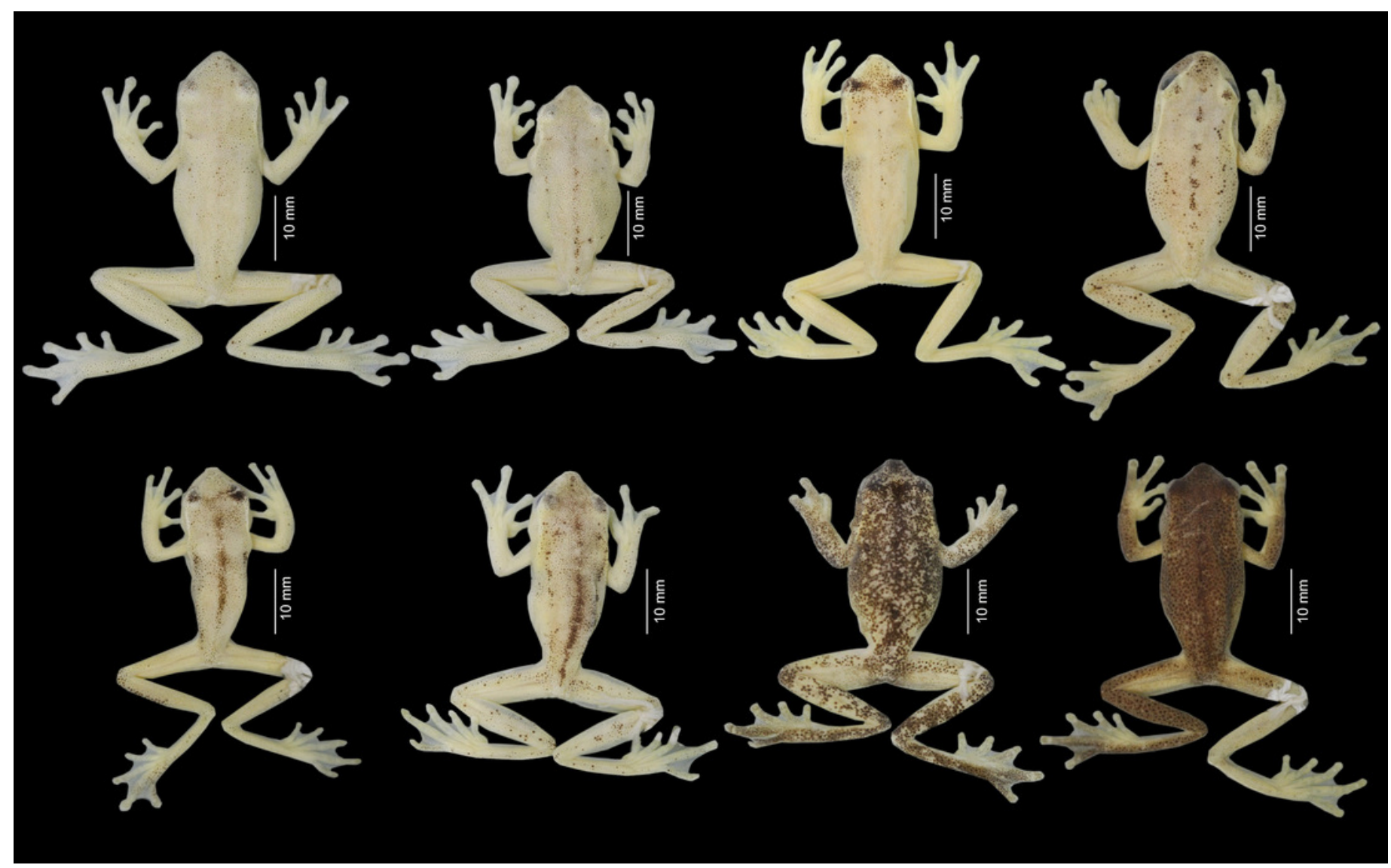


Figure 5

Figure 5. Comparisons in preservative of some species of the Hyloscirtus bogotensis group.

(A) H. alytolylax, DHMECN 5875; (B) H. mashpi, DHMECN 4289; (C) H. conscientia sp. nov., Holotype DHMECN 13973; (D). H. sp. candidate confirmed, DHMECN 1976; (E) H. sp. candidate not confirmed, DHMECN 0173; (F) H. simonsi, Holotype KU 169554; (G) H. candidate not confirmed, DHMECN 4750. Red arrows indicate the contour of the tip of the snout. Photographs MYM. 


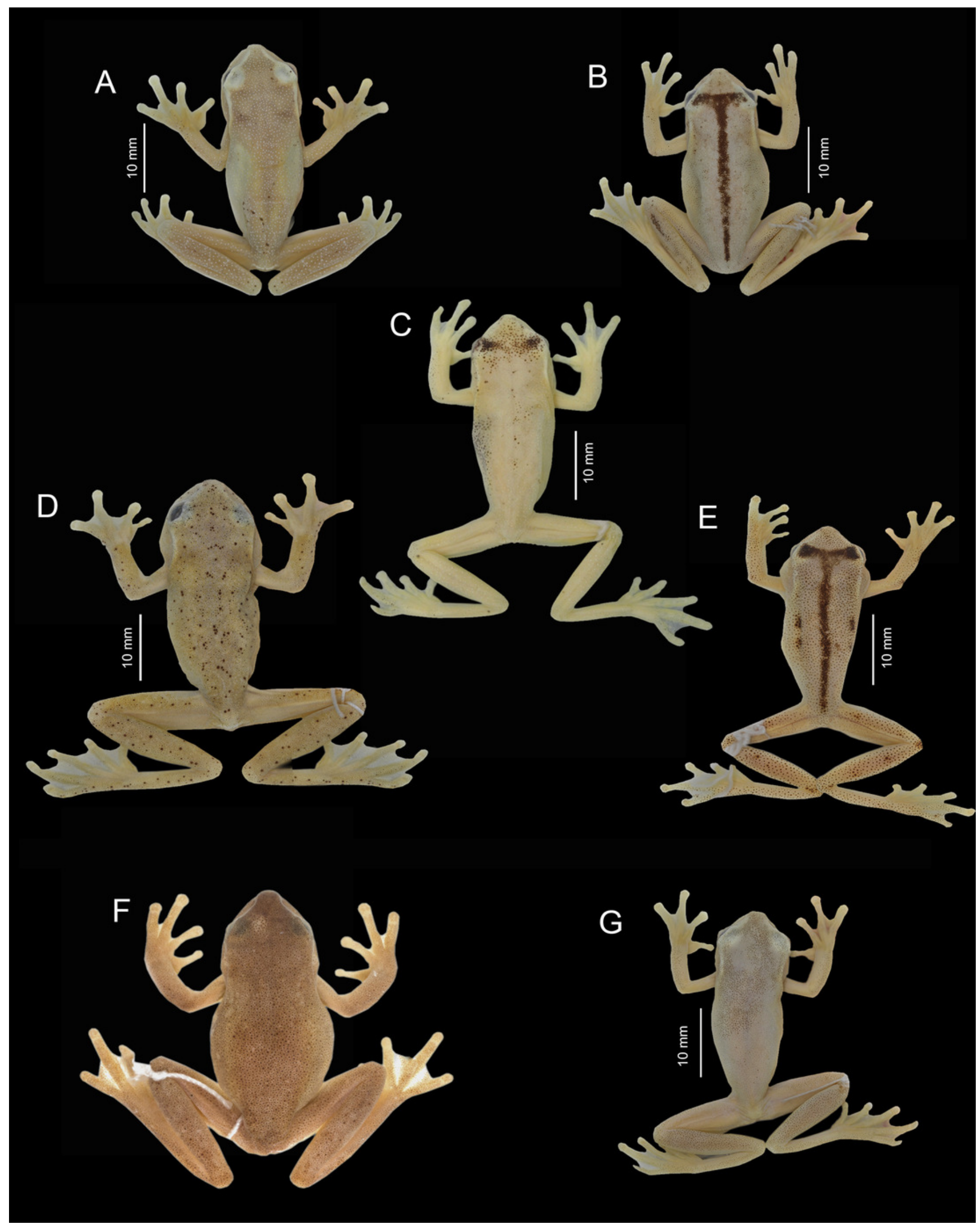




\section{Figure 6}

Figure 6. Comparison of tip snout in dorsal view of some preserved specimens of species in the Hyloscirtus bogotensis group.

(A) H. alytolylax, DHMECN 5875; (B) H. mashpi, DHMECN 4289; (C) H. conscientia sp. nov., Holotype DHMECN 13973; (D). H. sp. candidate confirmed, DHMECN 1976; (E) H. sp. candidate not confirmed, DHMECN 0173; (F) H. simonsi, Holotype KU 169554; (G) H. candidate not confirmed, DHMECN 4750. Red arrows indicate the contour of the tip of the snout. Photographs MYM. 

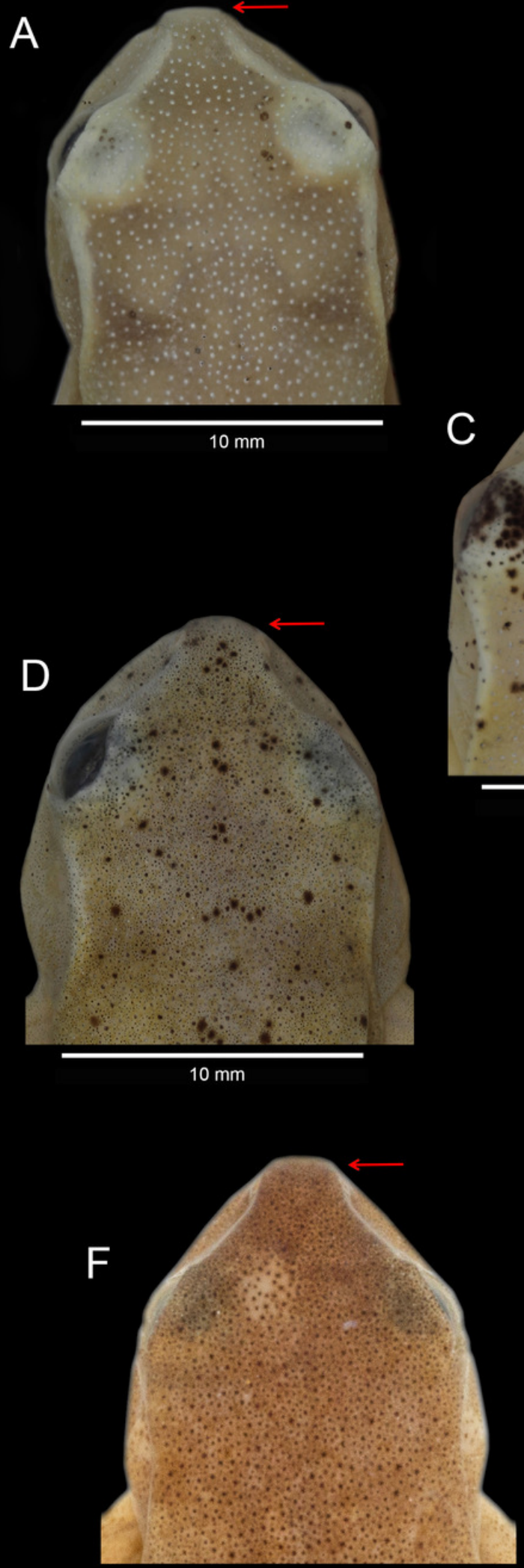
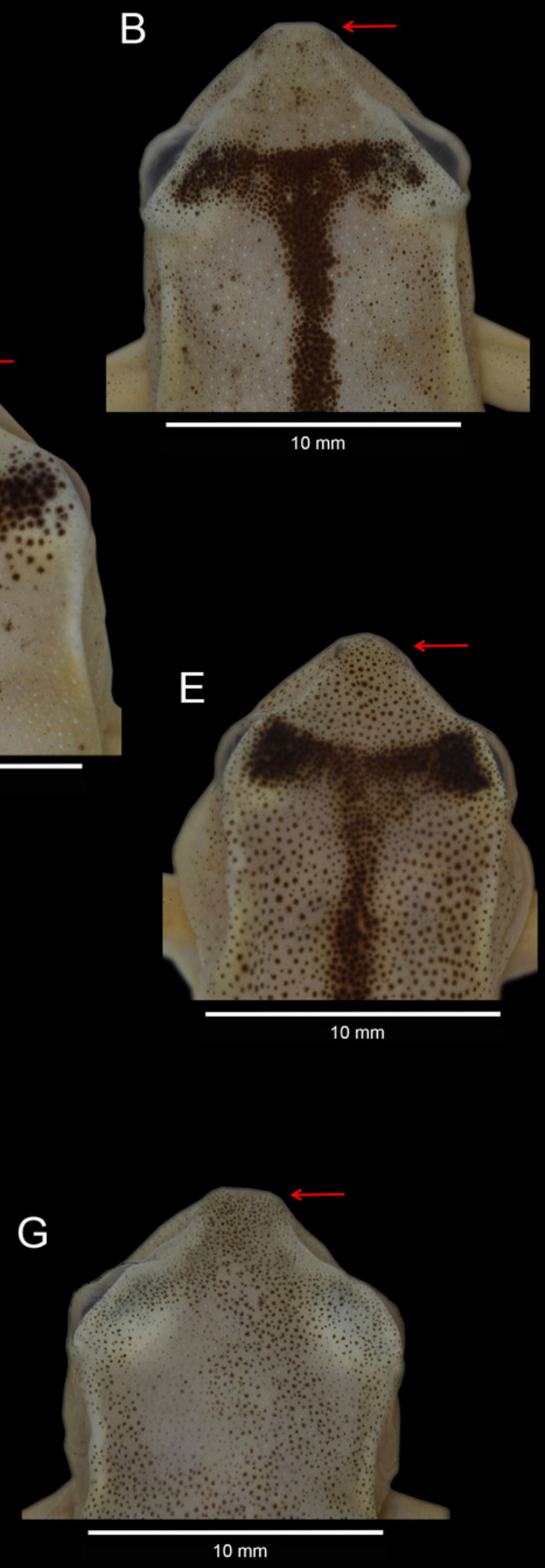


\section{Figure 7}

Figure 7. Comparison of dorsal skin texture of some preserved specimens of species in the Hyloscirtus bogotensis group.

(A) H. alytolylax, DHMECN 5875; (B) H. mashpi, DHMECN 7115; (C) H. sp. candidate confirmed, DHMECN 1976; (D) H. conscientia sp. nov., DHMECN 15142. Photographs by Lou Jost.

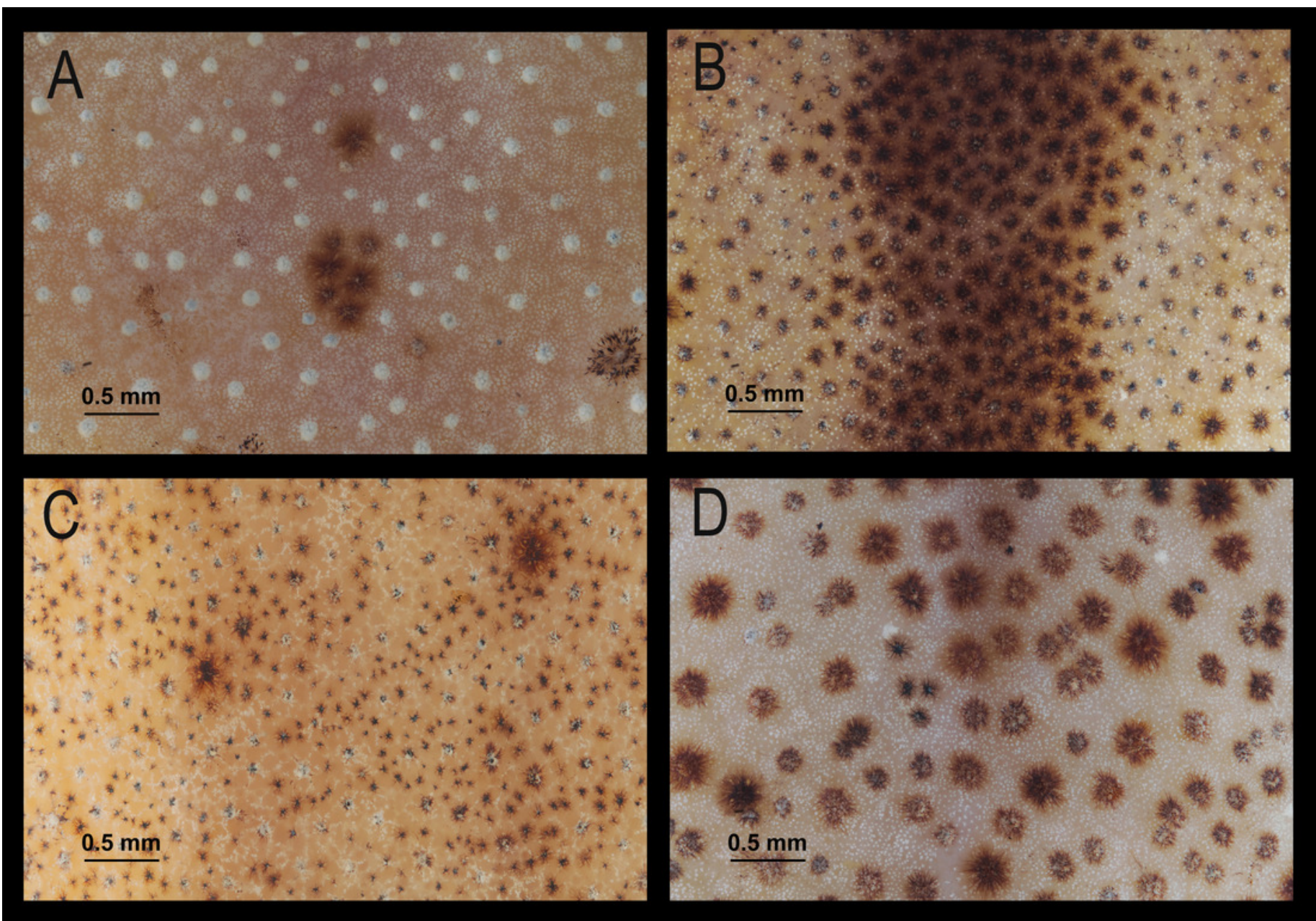


Figure 8

Figure 8. Principal component analysis from morphometric variables of the species of the Hylocirtus alytolylax complex.

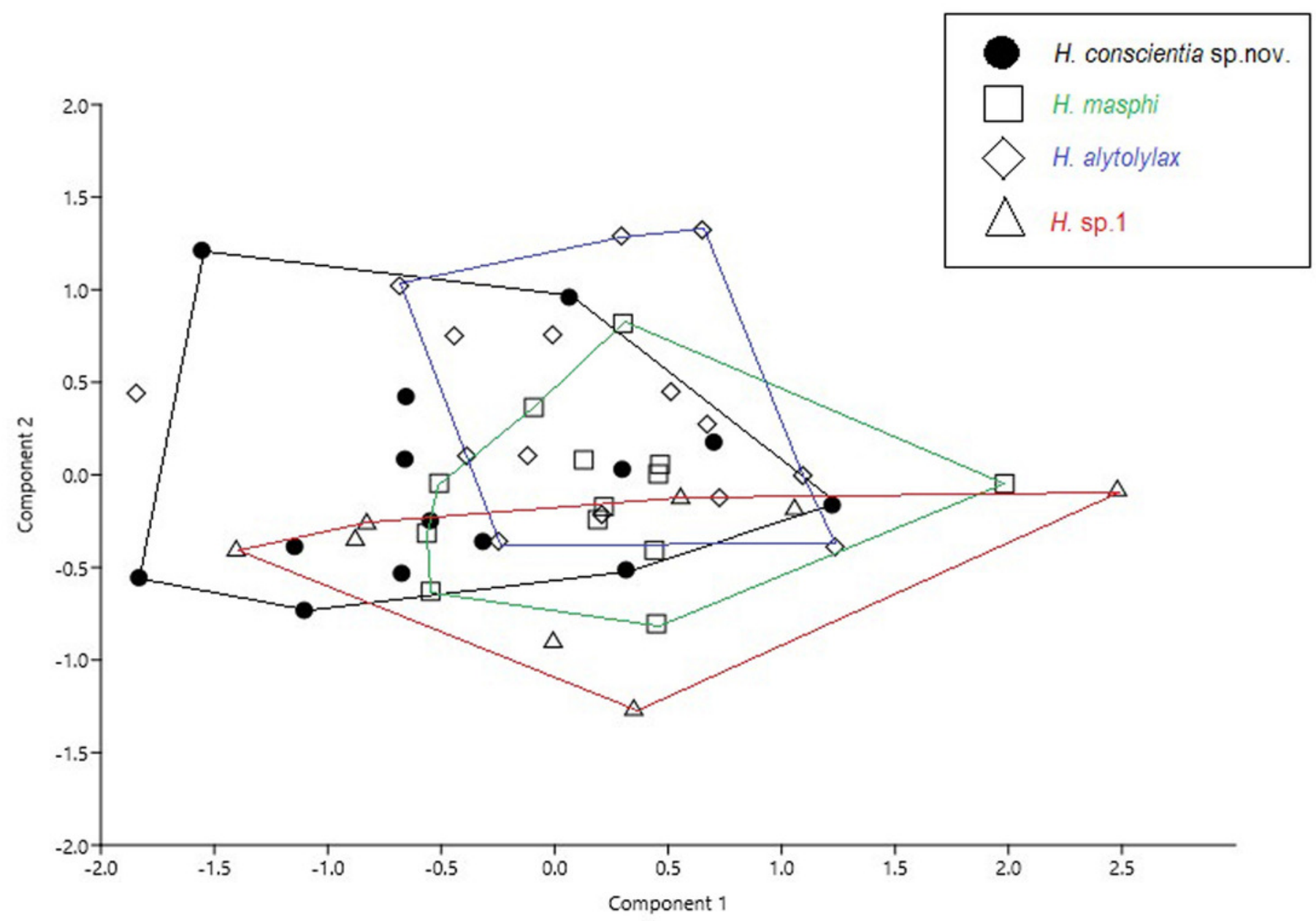


Figure 9

Figure 9. Comparison of morphometric data between Hyloscirtus conscientia sp. nov. and $H$. mashpi. 

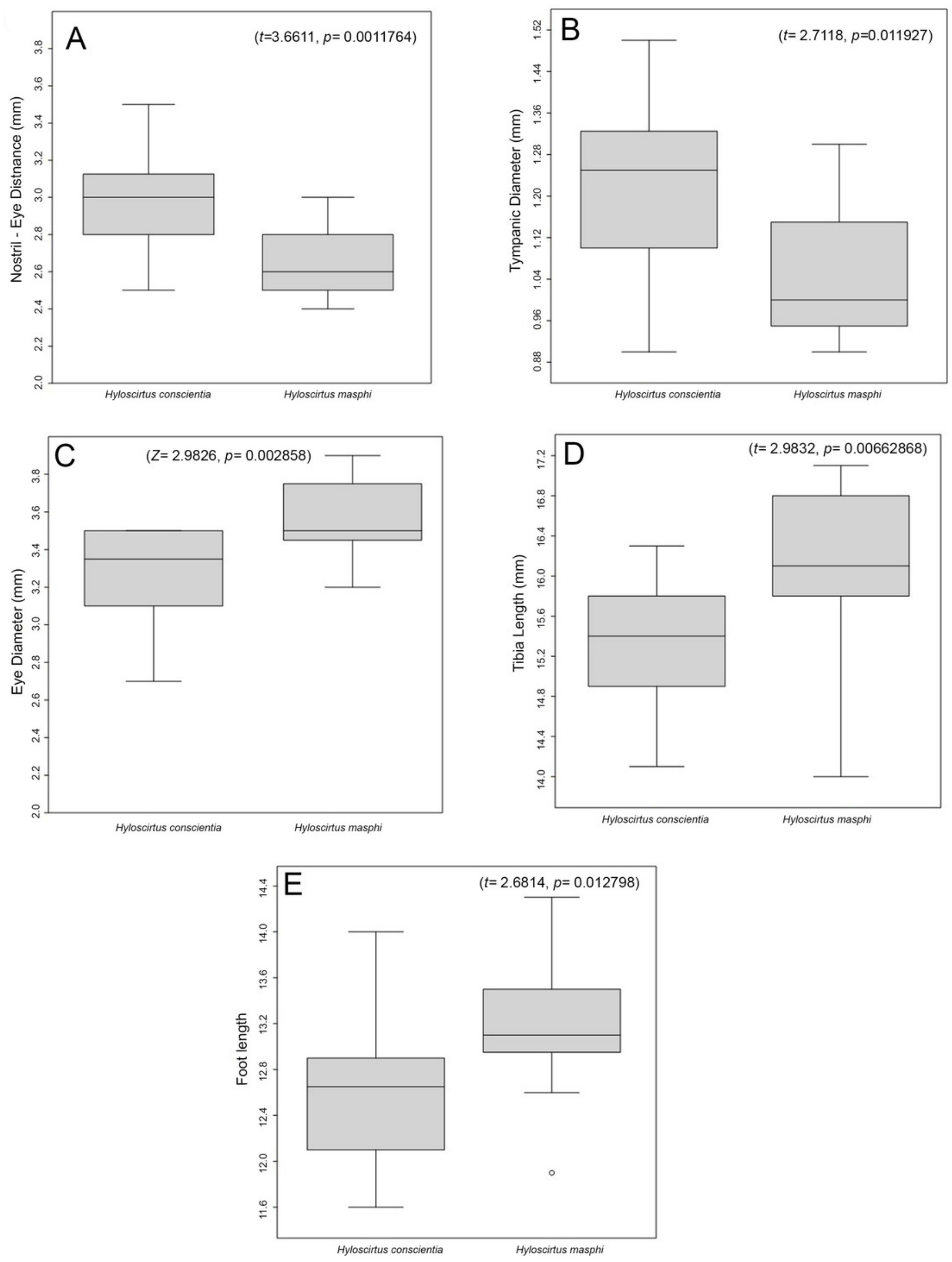

Peer] reviewing PDF | (2021:03:59101:1:2:NEW 24 Jun 2021) 


\section{Figure 10}

Figure 10. Comparison of live coloration of some species of the Hyloscirtus bogotensis Group.

(A) H. alytolylax, male, not collected, Estación Experimental La Favorita, province of Pichincha; (B) H. mashpi, male, DHMECN 4289, Reserva Mashpi, province of Pichincha; (C) H. conscientia, male, holotype DHMECN13973, Río Pailón Chico, Reserva Dracula, province of Carchi; (D) H. conscientia sp. nov., male, paratype DHMECN 13972, Río Pailón Chico, Reserva Dracula, province of Carchi; (E) H. sp. candidate confirmed, (DHMECN 3743); Reserva Buenaventura, province of El Oro; (F) H. sp. candidate not confirmed, El Baboso, province of Carchi. Specimens without scale. Photographs: MYM (A-E) and Mateo Vega-Yanez (F). 

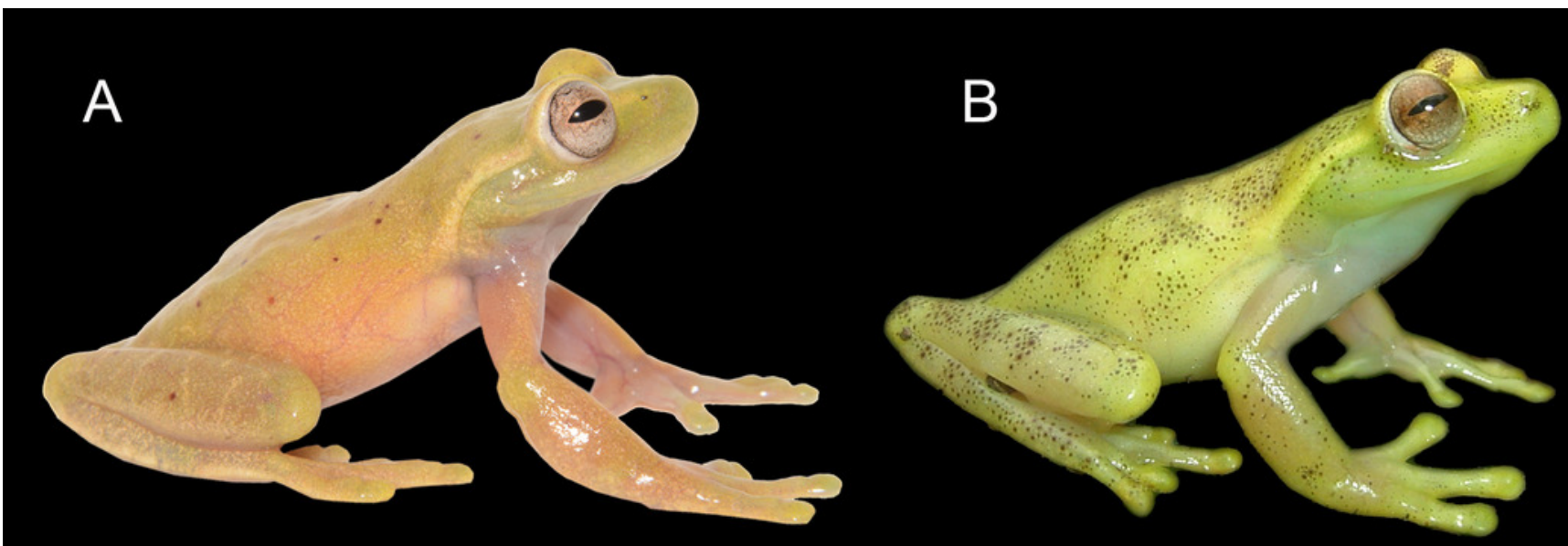

C
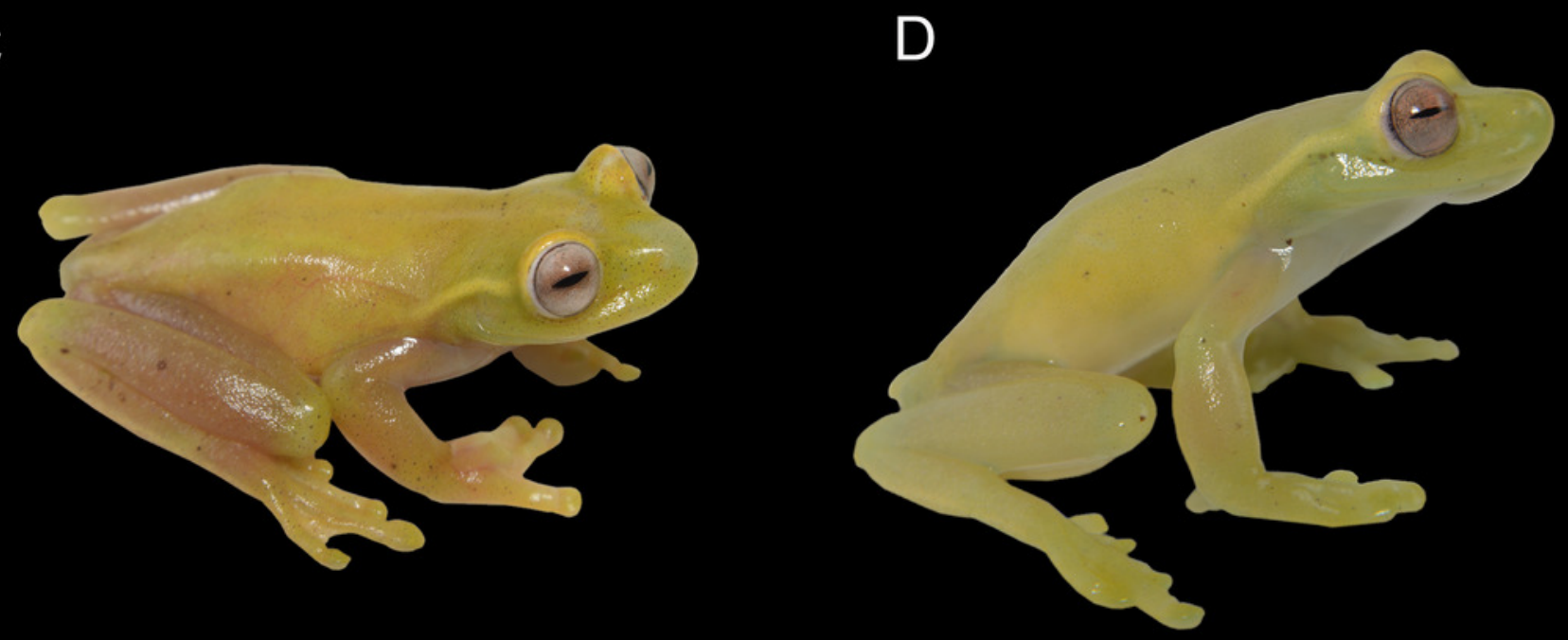

E
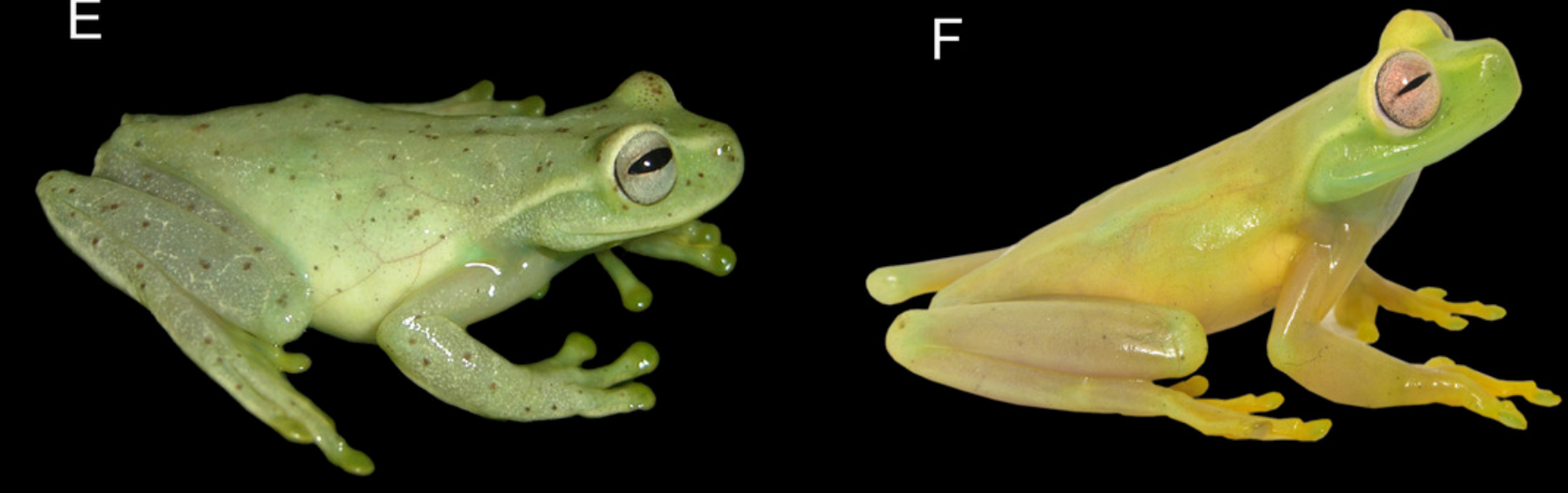
Figure 11

Figure 11. Variation in live coloration of Hyloscirtus conscientia sp. nov.

Individuals from Río Pailón Chico at Reserva Dracula. Not collected specimens, without scale. Photographs by MYM. 


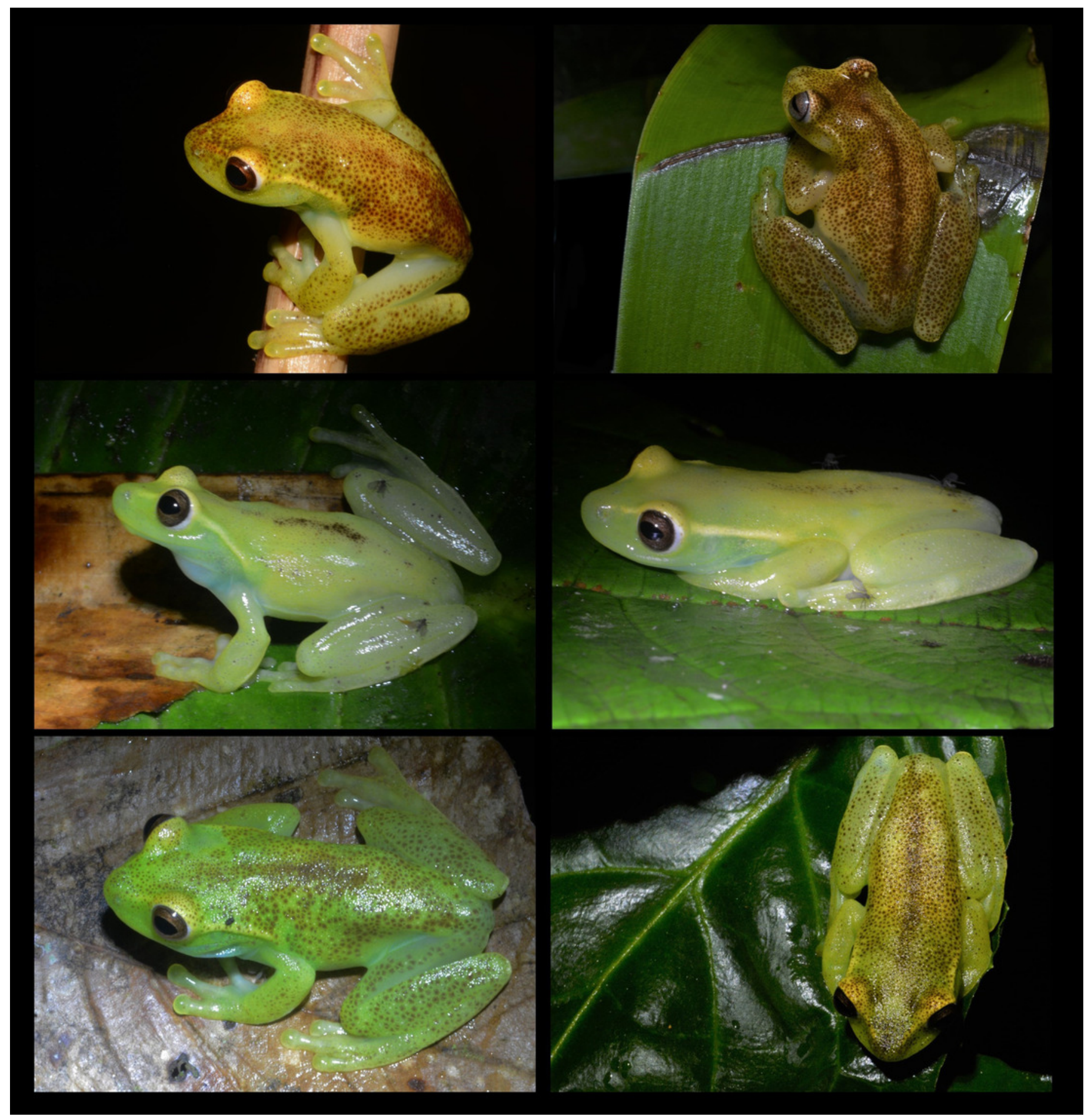




\section{Figure 12}

Figure 12. Oscillograms and spectrograms of the song of Hyloscirtus conscientia sp. nov. compared with the calls of several species of the Hyloscirtus bogotensis group.

(A) Hyloscirtus conscientia sp. nov. from the Guapilal Reserva Dracula (B) Hyloscirtus sp. 1 from El Baboso; (C) Hyloscirtus sp. 2 from El Oro; (D) H. alytolylax sensu stricto from Mindo; (E) H. palmeri from Tobar Donoso; (F) H. simmonsi from El Cauca-Colombia. For voucher datta see Table 6.
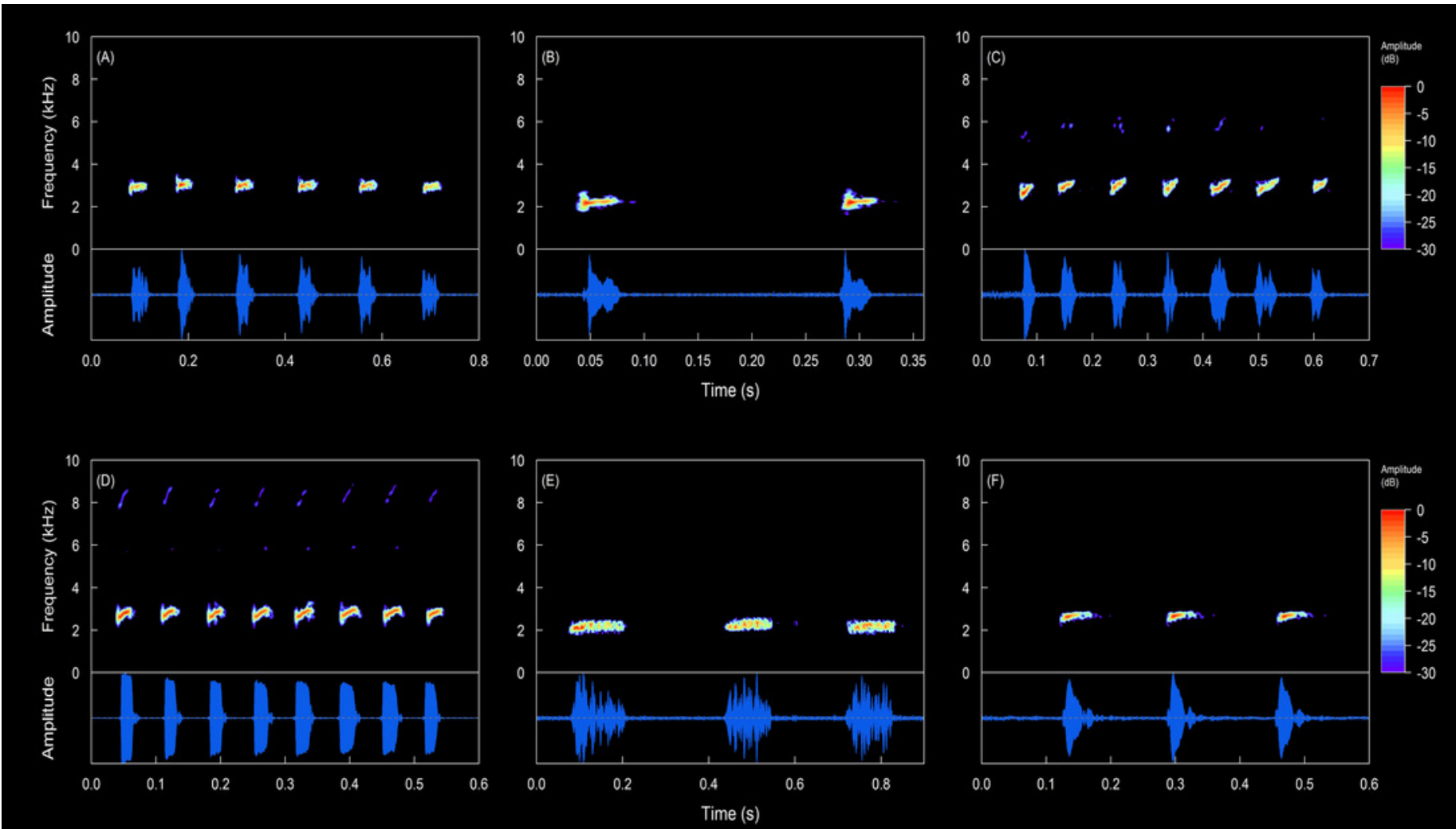
Figure 13

Figure 13. Box plot comparing variation of the spectral and temporal parameters of the notes of the Hyloscirtus conscientia sp. nov. of Guapilal, Reserva Dracula and Hyloscirtus sp. from El Baboso.
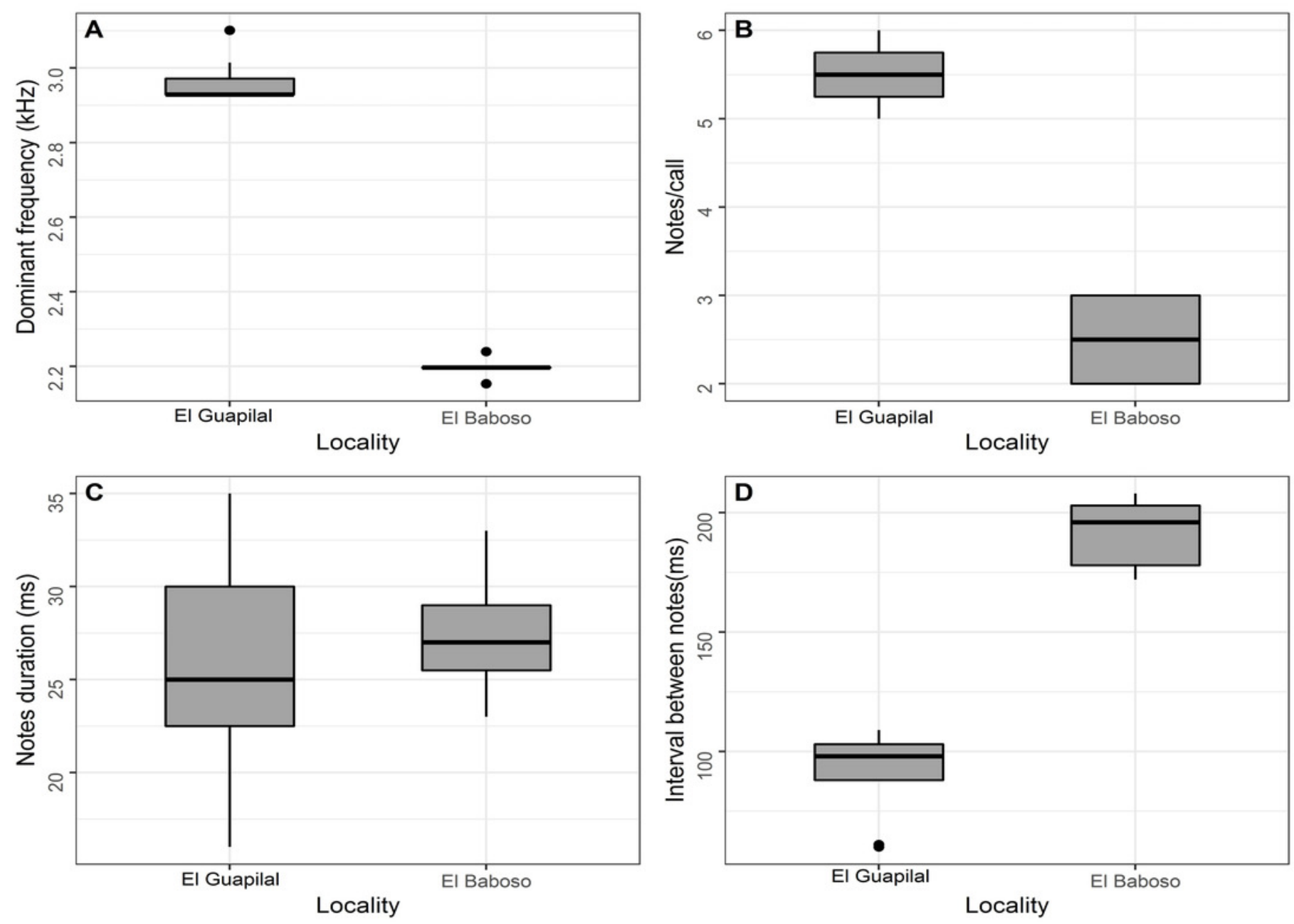


\section{Figure 14}

Figure 14. Map of Ecuador showing the distribution of Hyloscirtus conscientia sp. nov. and some species of the $H$. alytolylax complex

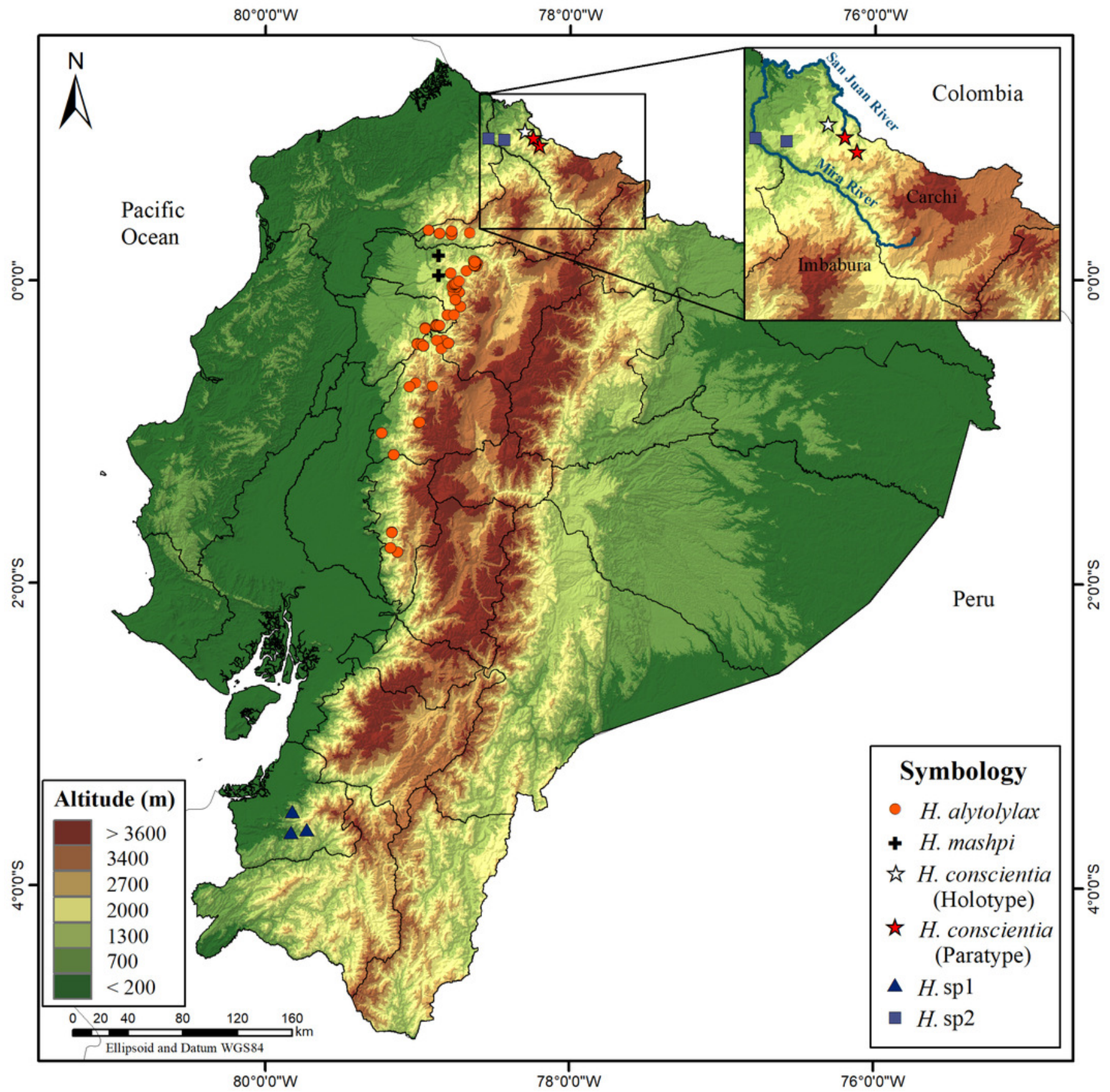




\section{Table $\mathbf{1}$ (on next page)}

Table 1. Matrix of rotated principal components obtained from morphometric variables of the species of the Hylocirtus alytolylax complex. 


\begin{tabular}{|c|c|c|c|c|}
\hline \multirow{2}{*}{$\begin{array}{c}\text { Morphological } \\
\text { variable }\end{array}$} & \multicolumn{4}{|c|}{ Components } \\
\hline & PC 1 & PC 2 & PC 3 & PC 4 \\
\hline & & - & & \\
\hline HW & 0.20728 & 0.039829 & 0.11563 & 0.33942 \\
\hline HL & 0.36365 & -0.2772 & 0.79021 & -0.2281 \\
\hline NED & $\begin{array}{c}- \\
0.0043312\end{array}$ & $\begin{array}{c}- \\
0.093427 \\
-\end{array}$ & 0.082997 & -0.31115 \\
\hline IND & 0.037503 & 0.055284 & 0.091971 & 0.037526 \\
\hline IOD & 0.13103 & 0.057463 & 0.12493 & 0.80219 \\
\hline EW & 0.0014943 & 0.11548 & 0.26451 & 0.19189 \\
\hline TD & -0.017409 & $\begin{array}{c}0.06092 \\
-\end{array}$ & 0.016531 & $\begin{array}{c}0.095268 \\
-\end{array}$ \\
\hline ED & 0.081547 & 0.056741 & 0.025114 & 0.069391 \\
\hline $\mathrm{TL}$ & 0.62551 & -0.57726 & -0.42938 & $\begin{array}{c}0.046531 \\
-\end{array}$ \\
\hline $\mathrm{HaL}$ & 0.34742 & 0.49207 & 0.15975 & 0.044192 \\
\hline FL & 0.53599 & 0.55756 & -0.22469 & -0.19029 \\
\hline \multicolumn{5}{|c|}{ Charge extraction sums } \\
\hline Total & 2.3096841 & 0.183752 & 0.984511 & 0.669702 \\
\hline$\%$ of Variance & 39.381 & 16.348 & 12.295 & 8.5572 \\
\hline$\%$ accumulated & 39.381 & 55.729 & 68.024 & 76.5812 \\
\hline
\end{tabular}

1

2 


\section{Table 2 (on next page)}

Table 2. Shapiro-Wilk normality test for morphometrics measurements of Hyloscirtus conscientia sp. $\mathrm{n}$. Asterisks indicate the degree of significance, $* \alpha=p<0.05$. 


\begin{tabular}{lcc}
\hline \multirow{2}{*}{ Character } & \multicolumn{2}{c}{ Shapiro-Wilk normality test $\mathrm{p}(\alpha$ 0.05) } \\
\cline { 2 - 3 } & Hyloscirtus conscientia & Hyloscirtus mashpi \\
\hline SVL & 0.1108 & 0.7421 \\
HW & 0.3272 & 0.1879 \\
HL & $0.04422^{*}$ & 0.8416 \\
NED & 0.396 & 0.4064 \\
IND & 0.7067 & $0.04807^{*}$ \\
IOD & 0.6504 & 0.2666 \\
EW & 0.4276 & 0.3608 \\
TD & 0.6723 & 0.09691 \\
ED & $0.04849 *$ & 0.8038 \\
TL & 0.972 & 0.1008 \\
HaL & 0.9366 & 0.7419 \\
FL & 0.1776 & 0.4987 \\
\hline
\end{tabular}

1 


\section{Table 3 (on next page)}

Table 3. Spectral and temporal values of the calls of species belonging to the Hyloscirtus bogotensis group.

The abbreviations used in the parameters correspond to: $\mathrm{kHz}=$ Kilohertz, $\mathrm{ms}=$ milliseconds . Of the values calculated using descriptive statistics, the following are detailed: minimum maximum (mean \pm standard deviation). In the analyzed sample, we indicate: number of specimens / calls / notes as $\mathrm{N}=\mathrm{X} / \mathrm{X} / \mathrm{X}$. 


\begin{tabular}{|c|c|c|c|c|c|c|c|}
\hline Variables & $\begin{array}{c}\text { Hyloscirtus } \\
\text { conscientia } \\
\text { sp.nov } \\
\mathrm{N}=1 / 8 / 16 \\
\end{array}$ & $\begin{array}{c}\text { Hyloscirtus } \\
\text { mashpi }\end{array}$ & $\begin{array}{c}\text { Hyloscirtus } \\
\text { alytolylax } \\
\mathrm{N}=1 / 10 / 88\end{array}$ & $\begin{array}{c}\text { Hyloscirtus } \\
\text { sp.1 } \\
\mathrm{N}=1 / 3 / 18 \\
\end{array}$ & $\begin{array}{l}\text { Hyloscirtus } \\
\quad \text { sp.2 } \\
\mathrm{N}=1 / 6 / 61 \\
\end{array}$ & $\begin{array}{c}\text { Hyloscirtus } \\
\text { palmeri } \\
\mathrm{N}=1 / 16 / 34\end{array}$ & $\begin{array}{c}\text { Hyloscirtus } \\
\text { simmonsi } \\
\mathrm{N}=3 / 16 / 61\end{array}$ \\
\hline Voucher & $\begin{array}{c}\text { DHMECN } \\
15004\end{array}$ & $\begin{array}{c}\text { Not } \\
\text { available }\end{array}$ & $\begin{array}{l}\text { Recording tape } \\
\text { KU } 826\end{array}$ & $\begin{array}{c}\text { DHMECN } \\
3831\end{array}$ & $\begin{array}{c}\text { DHMECN } \\
14897\end{array}$ & DHMECN 7988 & $\begin{array}{l}\text { Recording tape } \\
\text { KU } 765\end{array}$ \\
\hline Locality & $\begin{array}{l}\text { Cerro Negro } \\
\text { (Carchi) }\end{array}$ & $\begin{array}{c}\text { Mashpi } \\
\text { (Pichincha) }\end{array}$ & $\begin{array}{c}\text { Mindo } \\
\text { (Pichincha) }\end{array}$ & El Oro & $\begin{array}{l}\text { Río baboso } \\
\text { (Carchi) }\end{array}$ & $\begin{array}{l}\text { Tobar Donoso } \\
\text { (Carchi) }\end{array}$ & $\begin{array}{c}\text { Cauca } \\
\text { (Colombia) }\end{array}$ \\
\hline Type & 1 & - & 1 & 1 & 2 & 2 & 1 \\
\hline $\begin{array}{l}\text { Dominant } \\
\text { frequency } \\
\qquad(\mathrm{kHz})\end{array}$ & $\begin{array}{c}2.93-3.10 \\
(2.97 \pm 0.07)\end{array}$ & $\begin{array}{c}2.84-2.99 \\
(2.90 \pm 0.07)\end{array}$ & $\begin{array}{c}2.58-2.93 \\
(2.75 \pm 0.07)\end{array}$ & $\begin{array}{c}2.63-3.10 \\
(2.90 \pm 0.12)\end{array}$ & $\begin{array}{l}2.15-2.24 \\
(2.2 \pm 0.02)\end{array}$ & $\begin{array}{c}2.07-2.24 \\
(2.17 \pm 0.06)\end{array}$ & $\begin{array}{c}2.58-3.10 \\
(2.82 \pm 0.14)\end{array}$ \\
\hline $\begin{array}{l}\text { Call } \\
\text { duration } \\
(\mathrm{ms})\end{array}$ & $\begin{array}{c}470-632 \\
(551 \pm 114.55)\end{array}$ & $\begin{array}{l}330.9-380.2 \\
(353 \pm 11.55)\end{array}$ & $\begin{array}{c}422-715 \\
(538.10 \pm 91.18)\end{array}$ & $\begin{array}{c}455-522 \\
(497 \pm 49.79)\end{array}$ & $\begin{array}{c}255-479 \\
(358 \pm 109.91)\end{array}$ & $\begin{array}{c}134-2405 \\
(656.69 \pm 514.19)\end{array}$ & $\begin{array}{c}375-542 \\
(484.88 \pm 55.79)\end{array}$ \\
\hline $\begin{array}{l}\text { Notes per } \\
\text { call }\end{array}$ & $\begin{array}{c}5-6 \\
(5.50 \pm 1.49)\end{array}$ & $2-3$ & $\begin{array}{c}7-12 \\
(8.80 \pm 1.62)\end{array}$ & $\begin{array}{c}6-7 \\
(6.33 \pm 0.58)\end{array}$ & $\begin{array}{c}2-3 \\
(2.5 \pm 0.55)\end{array}$ & $\begin{array}{c}1-4 \\
(2.31 \pm 0.79)\end{array}$ & $\begin{array}{c}3-4 \\
(3.81 \pm 0.40)\end{array}$ \\
\hline $\begin{array}{c}\text { Note } \\
\text { duration } \\
(\mathrm{ms}) \\
\text { Time }\end{array}$ & $\begin{array}{c}16-35 \\
(26 \pm 6.13)\end{array}$ & - & $\begin{array}{c}8-29 \\
(22.74 \pm 4.86)\end{array}$ & $\begin{array}{c}19-30 \\
(24.83 \pm 2.53)\end{array}$ & $\begin{array}{c}23-33 \\
(27.47 \pm 2.64)\end{array}$ & $\begin{array}{c}74-185 \\
(130.47 \pm 36.30)\end{array}$ & $\begin{array}{c}26-54 \\
(40.56 \pm 6.47)\end{array}$ \\
\hline $\begin{array}{l}\text { between } \\
\text { notes } \\
(\mathrm{ms})\end{array}$ & $\begin{array}{c}60-109 \\
(90.89 \pm 18.30)\end{array}$ & $\begin{array}{r}115-162 \\
(139 \pm 13)\end{array}$ & $\begin{array}{c}35-60 \\
(43.67 \pm 5.42)\end{array}$ & $\begin{array}{c}43-87 \\
(65.12 \pm 11.11)\end{array}$ & $\begin{array}{c}172-208 \\
(191.67 \pm 14.74)\end{array}$ & $\begin{array}{c}114-702 \\
(292.45 \pm 172.80)\end{array}$ & $\begin{array}{c}101-134 \\
(117.69 \pm 7.64)\end{array}$ \\
\hline $\begin{array}{l}\text { Notes per } \\
\text { second } \\
\text { (rate) }\end{array}$ & $\begin{array}{l}7.69-11.76 \\
(8.81 \pm 1.43)\end{array}$ & $\begin{array}{c}0.17-0.50 \\
(0.36 \pm 0.99)\end{array}$ & $\begin{array}{c}13.16-16.95 \\
(15.18 \pm 0.89)\end{array}$ & $\begin{array}{c}8.93-14.29 \\
(11.32 \pm 1.48)\end{array}$ & $\begin{array}{c}4.20-5.13 \\
(4.58 \pm 0.36)\end{array}$ & $\begin{array}{c}1.20-4.20 \\
(2.73 \pm 0.90)\end{array}$ & $\begin{array}{c}5.92-7.52 \\
(6.34 \pm 0.32)\end{array}$ \\
\hline Source & This work & $\begin{array}{c}\text { Guayasamin } \\
\text { et al. } 2015\end{array}$ & This work & This work & This work & This work & This work \\
\hline
\end{tabular}




\section{Table 4 (on next page)}

Table 4. Genetic distances between Hyloscirtus conscientia sp. nov. and its most closely related taxa.

Values are presented as percentual distances calculated from uncorrected $p$ values. 


\begin{tabular}{lcccccc}
\hline & H. conscientia & H. sp.1 & H. alytolylax & H. mashpi & H. colymba & H. lascinius \\
\hline H. conscientia & 0.00 & 5.72 & $5.33-5.60$ & $6.25-6.38$ & 17.01 & $11.74-11.88$ \\
H. sp. 1 & & 0.00 & $2.73-2.99$ & $6.51-6.64$ & 15.82 & $11.99-12.13$ \\
H. alytolylax & & & $0.00-0.39$ & $6.39-6.66$ & $15.17-15.43$ & $10.82-11.21$ \\
H. mashpi & & & & $0.00-0.26$ & $16.74-16.87$ & $12.68-12.81$ \\
H. colymba & & & & & 0.00 & $15.73-15.86$ \\
H. lascinius & & & & & & 0.00 \\
\hline
\end{tabular}




\section{Table 5 (on next page)}

Table 5. Comparison of morphometric characters between Hyloscirtus conscientia sp. nov. and $H$. mashpi.

For each character, values $t$ and $z$, and $p$ are given, after rank, sample size (in brackets) and mean \pm standard deviation for each species. Asterisks show the degree of significance, $* \alpha=$ $p<0.05$. Measurements: Snout-Vent length (SVL), Tibia length (TL), Foot length (FL), Head length (HL), Head width (HW), Eyelid width (EW), Interorbital distance (IOD), Inter-narinal distance (IND), Eye-Narina distance (EN), Eye diameter (ED), Tympanic diameter (TD), Hand length (HaL). 


\begin{tabular}{lcccccc}
\hline Character & Hyloscirtus conscientia & Hyloscirtus mashpi & $t$ & $p$ & $Z$ & $p$ \\
\hline SVL & $29.6-33.3(14) 31.0 \pm 1.0$ & $28.7-32.2(13) 31.3 \pm 1.2$ & 0.86808 & 0.39361 & - & - \\
HW & $9.8-10.8(14) 10.2 \pm 0.3$ & $9.5-11(13) 10.3 \pm 0.5$ & 0.90816 & 0.37246 & - & - \\
HL & $10.0-12.2(14) 10.7 \pm 0.5$ & $9.9-11.7(13) 10.7 \pm 0.5$ & - & - & 0.073001 & 0.94181 \\
& & & & 0.0011764 & & \\
NED & $2.5-3.5(14) 3.0 \pm 0.3$ & $2.4-3.0(13) 2.6 \pm 0.2$ & 3.6611 & $*$ & & 0.98026 \\
IND & $2.0-3.0(14) 2.5 \pm 0.3$ & $2.1-2.8(13) 2.5 \pm 0.2$ & - & - & 0.024748 & - \\
IOD & $2.8-3.7(14) 3.3 \pm 0.2$ & $2.7-3.7(13) 3.3 \pm 0.3$ & 0.27696 & 0.78409 & - & - \\
EW & $2.2-3.1(14) 2.6 \pm 0.3$ & $2.0-2.9(13) 2.4 \pm 0.3$ & 1.5579 & 0.13182 & - & - \\
TD & $0.9-1.5(14) 1.2 \pm 0.2$ & $0.9-1.3(13) 1.1 \pm 0.1$ & 2.7118 & $0.011927 *$ & - & 0.0028578 \\
& & & & & & $*$ \\
ED & $2.7-3.5(14) 3.3 \pm 0.2$ & $3.2-3.9(13) 3.6 \pm 0.2$ & - & - & 2.9826 & - \\
& & & & 0.0062868 & & - \\
TL & $14.1-16.3(14) 15.3 \pm 0.6$ & $14.0-17.1(13) 15.1 \pm 0.8$ & 2.9832 & $*$ & - & - \\
HaL & $8.4-10.4(14) 9.3 \pm 0.5$ & $8.6-10.4(13) 9.6 \pm 0.5$ & 1.3187 & 0.19924 & - & - \\
FL & $11.6-14.0(14) 12.6 \pm 0.6$ & $11.9-14.3(13) 13.2 \pm 0.6$ & 2.6814 & $0.012798^{*}$ & - & - \\
\hline \multicolumn{1}{l}{1} & & & & & &
\end{tabular}




\section{Table 6(on next page)}

Table 6. Variation of type series of Hyloscirtus conscientia sp. nov., with an asterisk (*) the Holotype is marked. 


\begin{tabular}{|c|c|c|c|c|c|c|c|c|c|c|c|c|c|}
\hline Code collection & SEX & SVL & HW & HL & NED & IND & IOD & EW & TD & ED & TL & HaL & FL \\
\hline DHMECN13973* & $\widehat{\sigma}$ & 31.7 & 10.4 & 10.4 & 2.6 & 2.7 & 3.5 & 2.7 & 1.3 & 3.5 & 15.7 & 9.6 & 12.8 \\
\hline DHMECN15004 & $\hat{\jmath}$ & 32.25 & 10.5 & 12.2 & 3.5 & 2.5 & 2.9 & 3 & 0.9 & 3.5 & 16.3 & 10.4 & 14 \\
\hline DHMECN15138 & $\hat{0}$ & 31.7 & 9.9 & 10.4 & 3 & 2.5 & 3.1 & 2.7 & 1.3 & 3.4 & 15.8 & 9.6 & 12.1 \\
\hline DHMECN15139 & $\hat{0}$ & 30.5 & 10.8 & 10.6 & 3.1 & 2.7 & 3.5 & 2.5 & 1.2 & 3.2 & 15.8 & 9 & 12.5 \\
\hline DHMECN15140 & $\hat{0}$ & 33.3 & 10 & 11.1 & 3.5 & 2.4 & 3.7 & 2.6 & 1 & 3.2 & 16.1 & 9.3 & 12.9 \\
\hline DHMECN13968 & $\hat{0}$ & 29.6 & 10.2 & 11.1 & 3 & 2.9 & 3.3 & 2.2 & 1.1 & 3.5 & 15.4 & 9.2 & 12.8 \\
\hline DHMECN13969 & $\hat{0}$ & 30.2 & 9.8 & 10.5 & 2.8 & 2.4 & 3 & 2.8 & 1.3 & 3.5 & 14.6 & 10 & 12.8 \\
\hline DHMECN13970 & $\hat{\jmath}$ & 30.6 & 9.9 & 10.8 & 3 & 2.3 & 2.8 & 2.2 & 1.5 & 3.1 & 15.2 & 8.8 & 12.1 \\
\hline DHMECN13971 & $\hat{0}$ & 30.2 & 10 & 10.2 & 2.5 & 2.4 & 3.2 & 2.4 & 1.3 & 3.1 & 14.5 & 9.4 & 12.1 \\
\hline DHMECN13972 & $\sigma^{\lambda}$ & 30.6 & 10.3 & 10.5 & 2.8 & 2 & 3.3 & 2.2 & 1.1 & 2.7 & 15.2 & 9 & 12.2 \\
\hline DHMECN13974 & $\hat{0}$ & 31.4 & 10.2 & 10 & 2.9 & 2.6 & 3.1 & 2.4 & 1.5 & 3 & 14.1 & 9.6 & 13 \\
\hline DHMECN13975 & $\hat{0}$ & 30.7 & 10.7 & 10.6 & 2.8 & 3 & 3.7 & 2.9 & 1.2 & 3.3 & 14.9 & 8.4 & 11.6 \\
\hline DHMECN13976 & 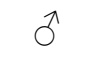 & 30.5 & 10.2 & 11 & 3 & 2.4 & 3.6 & 3.1 & 1.4 & 3.4 & 15.1 & 8.8 & 12.2 \\
\hline DHMECN13977 & $\hat{0}$ & 30.4 & 9.8 & 10.8 & 3.2 & 2.6 & 3.3 & 2.8 & 1.1 & 3.4 & 15.4 & 9.2 & 12.9 \\
\hline DHMECN16007 & q & 40 & 13.75 & 14.42 & 3.62 & 3.12 & 5.2 & 3.32 & 1.21 & 4.71 & 22.4 & 11.76 & 17.67 \\
\hline DHMECN16114 & q & 37.35 & 12.15 & 12.63 & 2.86 & 2.78 & 4.5 & 2.99 & 1.41 & 3.53 & 19.43 & 12.17 & 17.08 \\
\hline DHMECN16115 & q & 34.68 & 11.35 & 12.47 & 2.84 & 2.66 & 3.81 & 3.06 & 1.63 & 4.2 & 17.22 & 11.13 & 14.62 \\
\hline Rank males & & $\begin{array}{c}29.6- \\
33.3(14) \\
31.0 \pm 1.0\end{array}$ & $\begin{array}{c}9.8-10.8 \\
(14) 10.2 \\
\pm 0.3\end{array}$ & $\begin{array}{c}10.0- \\
12.2(14) \\
10.7 \pm 0.5\end{array}$ & $\begin{array}{c}2.5-3.5 \\
(14) 3.0 \pm \\
0.3\end{array}$ & $\begin{array}{c}2.0-3.0 \\
(14) 2.5 \pm \\
0.3\end{array}$ & $\begin{array}{c}2.8-3.7 \\
(14) 3.3 \pm \\
0.2\end{array}$ & $\begin{array}{c}2.2-3.1 \\
(14) 2.6 \pm \\
0.3\end{array}$ & $\begin{array}{c}0.9-1.5 \\
\text { (14) } 1.2 \pm \\
0.2\end{array}$ & $\begin{array}{c}2.7-3.5 \\
(14) 3.3 \pm \\
0.2\end{array}$ & $\begin{array}{c}14.1- \\
16.3(14) \\
15.3 \pm 0.6\end{array}$ & $\begin{array}{c}8.4-10.4 \\
\text { (14) } 9.3 \pm \\
0.5\end{array}$ & $\begin{array}{c}11.6- \\
14.0(14) \\
12.6 \pm 0.6\end{array}$ \\
\hline Rank females & & $\begin{array}{l}34.7-40 \\
\text { (3) } 37.3 \pm \\
2.6\end{array}$ & $\begin{array}{c}11.4- \\
13.8(3) \\
12.4 \pm 1.2 \\
\end{array}$ & $\begin{array}{c}12.5- \\
14.4(3) \\
13.2 \pm 1.1\end{array}$ & $\begin{array}{c}2.6-3.8 \\
\text { (3) } 3.1 \pm \\
0.4\end{array}$ & $\begin{array}{c}2.8-3.6 \\
\text { (3) } 2.9 \pm \\
0.3\end{array}$ & $\begin{array}{c}3.8-5.2 \\
\text { (3) } 4.5 \pm \\
0.7\end{array}$ & $\begin{array}{c}2.9-3.3 \\
\text { (3) } 3.1 \pm \\
0.2\end{array}$ & $\begin{array}{c}1.2-1.6 \\
\text { (3) } 1.4 \pm \\
0.2\end{array}$ & $\begin{array}{c}3.5-4.7 \\
\text { (3) } 4.5 \pm \\
0.6\end{array}$ & $\begin{array}{c}17.2- \\
22.4(3) \\
19.68 \pm \\
2.6 \\
\end{array}$ & $\begin{array}{c}11.1- \\
12.2(3) \\
11.7 \pm 0.5\end{array}$ & $\begin{array}{c}14.6- \\
17.7(3) \\
16.5 \pm 1.6\end{array}$ \\
\hline
\end{tabular}


Table 7 (on next page)

Appendix 1. List of specimens examined 
1 Appendix 1. List of specimens examined. Hyloscirtus alytolylax (15): Ecuador: Imbabura (2): 2 Concesión Llumiragua, DHMECN 13281; Río Naranjal, DHMECN 3518-19; Pichincha (13): 3 Chiriboga, Estación Experimental "La Favorita" DHMECN 999; Las Tolas DHMECN 4338-39, 4 DHMECN 5815; Lloa Mindo- San Carlos, DHMECN 5875-77; Reserva las Gralarias DHMECN 5 10314-15; Saragoza la Union -Rio Cinto DHMECN 5878-79, DHMECN 7377-7378; Reserva 6 Maquipucuna, QCAZ67790-67803. Hyloscirtus mashpi (9): Ecuador: Pichincha (9): Bosque 7 Protector Mashpi, DHMECN 4288-94, DHMECN 7115-16. Hyloscirtus palmeri (12): Ecuador: 8 Carchi (4): Destacamento Militar, Tobar Donoso, DHMECN 7988; Estero 1 Sendero Awa, Tobar 9 Donoso, DHMECN 6684; Río San Juan, Tobar Donoso, DHMECN 12672, 6685; Esmeraldas (8):

10 Río Bogotá DHMECN 3214; Reserva Biológica Canandé DHMECN 2941-44, DHMECN 954849; Pichincha (1): Saguangal, DHMECN 4462; Bosque Protector Mashpi, DHMECN 4295. Hyloscirtus simonsi (2): Colombia: Dpto. del Valle, Río Calima, 1.5 km (by road) W, KU 169554 (Holotype), KU 169555. Hyloscirtus sp.1 (9): Ecuador: El Oro (2) Cascadas de Manuel DHMECN 11510; El Birón, DHMECN 13795; Limón Playa, DHMECN 10782; Reserva Biológica Buenaventura, DHMECN 1975-77, DHMECN 2548, DHMECN 3831-32, DHMECN 9442-47; Sendero Nalacapac, DHMECN 10867. Hyloscirtus sp.2 (13): Ecuador: Carchi (12): Cabeceras del Río Baboso, DHMECN 1000-07; El Baboso, cascada DHMECN 14910; El Baboso, zona alta DHMECN14897, 14901, El Goaltal, DHMECN 1045; Esmeraldas (1): Alto Tambo-Río Negro, DHMECN 3281. 


\section{Table 8(on next page)}

Appendix 2. Comparative table of characters of some species of the Hyloscirtus bogotensis group of the western Andes 
Appendix 2. Comparative table of characters of some species of the Hyloscirtus bogotensis group of the western Andes.

\begin{tabular}{|c|c|c|c|c|c|c|c|}
\hline Species & $\begin{array}{l}\text { SVL (males) } \\
\text { in } \mathrm{mm}\end{array}$ & $\begin{array}{l}\text { SVL (females) } \\
\text { in } \mathbf{~ m m}\end{array}$ & Snout Shape & Tip of snout & Anillus tympanic & Supranal fold & Calcars \\
\hline $\begin{array}{c}\text { Hyloscirtus } \\
\text { concientia sp. nov }\end{array}$ & $\begin{array}{c}29.6-33.3(14) \\
\text { mean= } 31\end{array}$ & $\begin{array}{l}34.7-40(3) \\
\text { mean }=37.3\end{array}$ & $\begin{array}{c}\text { snout subacuminate } \\
\text { in dorsal view and } \\
\text { rounded in lateral } \\
\text { view }\end{array}$ & Rounded & conspicuos & present & absent \\
\hline Hyloscirtus mashpi & $\begin{array}{c}28.7-33.8(14) \\
\text { mean }=31.5\end{array}$ & $\begin{array}{l}37-38.5(2) \\
\text { mean }=37.8\end{array}$ & $\begin{array}{l}\text { snout rounded in } \\
\text { dorsal view and } \\
\text { lateral view }\end{array}$ & Truncate & inconspicuos & absent & absent \\
\hline $\begin{array}{l}\text { Hyloscirtus } \\
\text { alytolylax }\end{array}$ & $\begin{array}{c}32.1-37.0(13) \\
\text { mean }=34.85\end{array}$ & $\begin{array}{c}37.2-43.9(15) \\
\text { mean }=40.3\end{array}$ & $\begin{array}{l}\text { snout rounded in } \\
\text { dorsal view and } \\
\text { lateral view }\end{array}$ & Truncate & conspicuos & present & absent \\
\hline $\begin{array}{l}\text { Hyloscirtus } \\
\text { palmeri }\end{array}$ & $\begin{array}{c}34.9-42.6(15) \\
\text { mean }=39.6\end{array}$ & $\begin{array}{c}35.7-50.0(7) \\
\text { mean }=44.4\end{array}$ & $\begin{array}{c}\text { snout rounded in } \\
\text { dorsal view and } \\
\text { truncate in lateral } \\
\text { view }\end{array}$ & Truncate & conspicuos & present & present \\
\hline $\begin{array}{l}\text { Hyloscirtus } \\
\text { simmonsi }\end{array}$ & $\begin{array}{l}35-37.8(12) \\
\text { mean }=39.7\end{array}$ & $36.6(1)$ & $\begin{array}{l}\text { snout subacuminate } \\
\text { in dorsal view and } \\
\text { inclined } \\
\text { posteroventrally } \\
\text { from tipo to margen } \\
\text { of jaw in lateral view }\end{array}$ & Truncate & barely evident & absent & absent \\
\hline
\end{tabular}

3 
Continued Appendix 2...

11

\begin{tabular}{|c|c|c|c|c|c|c|c|}
\hline Species & $\begin{array}{l}\text { Dorsal coloration } \\
\text { pattern in live }\end{array}$ & Iridophoros & Melanophoros & $\begin{array}{c}\text { Canthal } \\
\text { stripe cream }\end{array}$ & $\begin{array}{l}\text { Supraocular } \\
\text { stripe cream }\end{array}$ & $\begin{array}{l}\text { Tympanic } \\
\text { stripe cream }\end{array}$ & Sourse \\
\hline $\begin{array}{c}\text { Hyloscirtus } \\
\text { concientia sp. nov }\end{array}$ & $\begin{array}{l}\text { dorsum usually pale } \\
\text { yellowish-green, } \\
\text { usually with a thin } \\
\text { brown mid-dorsal } \\
\text { stripe }\end{array}$ & $\begin{array}{l}\text { with individual } \\
\text { iridophores } \\
\text { sometimes } \\
\text { packed on top of } \\
\text { melanophores } \\
\text { but never } \\
\text { forming dots }\end{array}$ & $\begin{array}{l}\text { melanophores } \\
\text { smaller and more } \\
\text { densely packed }\end{array}$ & present & Present & Present & This work \\
\hline Hyloscirtus mashpi & $\begin{array}{l}\text { pale greenish yellow } \\
\text { with a brown dorsal } \\
\text { midline }\end{array}$ & $\begin{array}{l}\text { iridophores } \\
\text { forming dots, } \\
\text { scarcely } \\
\text { distributed across } \\
\text { dorsum }\end{array}$ & $\begin{array}{l}\text { mid-dorsal stripe } \\
\text { formed by } \\
\text { melanophores larger } \\
\text { and less dense }\end{array}$ & present & Present & Present & $\begin{array}{c}\text { Guayasamin et al. (2015), } \\
\text { this work }\end{array}$ \\
\hline $\begin{array}{l}\text { Hyloscirtus } \\
\text { alytolylax }\end{array}$ & $\begin{array}{l}\text { greenish brown to } \\
\text { pale green }\end{array}$ & $\begin{array}{l}\text { iridophores } \\
\text { forming } \\
\text { abundant dots }\end{array}$ & absent & present & Present & Present & Duellman 1972, this work \\
\hline $\begin{array}{l}\text { Hyloscirtus } \\
\text { palmeri }\end{array}$ & $\begin{array}{l}\text { dark green back with } \\
\text { few irregular white } \\
\text { or cream spots }\end{array}$ & absent & $\begin{array}{l}\text { when present, evenly } \\
\text { distributed on the } \\
\text { back }\end{array}$ & absent & Absent & Absent & Duellman 1972, this work \\
\hline $\begin{array}{l}\text { Hyloscirtus } \\
\text { simmonsi }\end{array}$ & $\begin{array}{l}\text { Dull green with } \\
\text { minute brown flecks }\end{array}$ & absent & $\begin{array}{l}\text { thickly covered by } \\
\text { melanophores }\end{array}$ & absent & Absent & Absent & Duellman 1989, this work \\
\hline
\end{tabular}

